\title{
Life cycle assessment as development and decision support tool for wastewater resource recovery technology
}

Fang, Linda L.; Valverde Perez, Borja; Damgaard, Anders; Plósz, Benedek G.; Rygaard, Martin

Published in:

Water Research

Link to article, DOI:

10.1016/j.watres.2015.10.016

Publication date:

2016

Document Version

Peer reviewed version

Link back to DTU Orbit

Citation (APA):

Fang, L. L., Valverde Perez, B., Damgaard, A., Plósz, B. G., \& Rygaard, M. (2016). Life cycle assessment as development and decision support tool for wastewater resource recovery technology. Water Research, 88, 538549. https://doi.org/10.1016/j.watres.2015.10.016

\section{General rights}

Copyright and moral rights for the publications made accessible in the public portal are retained by the authors and/or other copyright owners and it is a condition of accessing publications that users recognise and abide by the legal requirements associated with these rights.

- Users may download and print one copy of any publication from the public portal for the purpose of private study or research.

- You may not further distribute the material or use it for any profit-making activity or commercial gain

- You may freely distribute the URL identifying the publication in the public portal 


\section{Accepted Manuscript}

Life cycle assessment as development and decision support tool for wastewater resource recovery technology

Linda L. Fang, Borja Valverde-Pérez, Anders Damgaard, Benedek Gy. Plósz, Martin Rygaard

PII: S0043-1354(15)30282-7

DOI: 10.1016/j.watres.2015.10.016

Reference: WR 11577

To appear in: Water Research

Received Date: 13 May 2015

Revised Date: 18 September 2015

Accepted Date: 12 October 2015

Please cite this article as: Fang, L.L., Valverde-Pérez, B., Damgaard, A., Plósz, B.G., Rygaard, M., Life cycle assessment as development and decision support tool for wastewater resource recovery technology, Water Research (2015), doi: 10.1016/j.watres.2015.10.016.

This is a PDF file of an unedited manuscript that has been accepted for publication. As a service to our customers we are providing this early version of the manuscript. The manuscript will undergo copyediting, typesetting, and review of the resulting proof before it is published in its final form. Please note that during the production process errors may be discovered which could affect the content, and all legal disclaimers that apply to the journal pertain. 


\section{Graphical abstract}

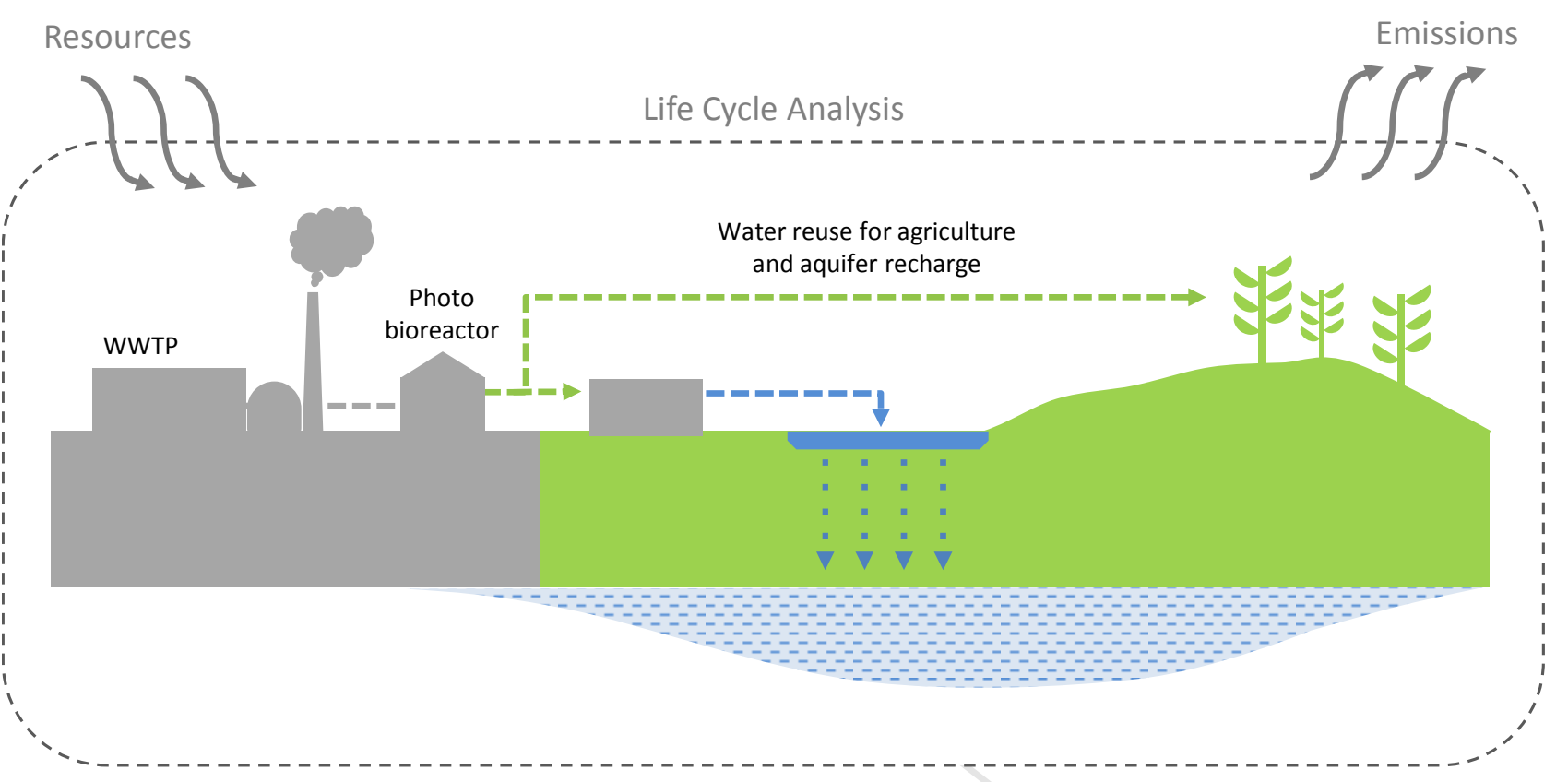




\section{Life cycle assessment as development and decision}

\section{2 support tool for wastewater resource recovery}

\section{3 technology}

Linda L. Fang ${ }^{1, *}$, Borja Valverde-Pérez ${ }^{1}$, Anders Damgaard ${ }^{1}$, Benedek Gy. Plósz ${ }^{1, *}$, Martin Rygaard ${ }^{1}$

${ }^{1}$ Department of Environmental Engineering, Technical University of Denmark, Miljøvej, Building 113, 2800 Kgs. Lyngby, Denmark,

Email: linda.fang@mail.mcgill.ca; beep@env.dtu.dk; Telephone: +45 45251474

* Corresponding authors

\section{Keywords}

9 Resource recovery, life cycle assessment, technology development, wastewater treatment, enhanced

10 biological phosphorus removal, algal cultivation

\section{Abstract}

Life cycle assessment (LCA) has been increasingly used in the field of wastewater treatment where the focus has been to identify environmental trade-offs of current technologies. In a novel approach, we use LCA to support early stage research and development of a biochemical system for wastewater resource recovery. The freshwater and nutrient content of wastewater are recognized as potential valuable resources that can be recovered for beneficial reuse. Both recovery and reuse are intended to address existing environmental concerns, for example water scarcity and use of non-renewable phosphorus. However, the resource recovery may come at the cost of unintended environmental impacts. One promising recovery system, referred to as TRENS, consists of an enhanced biological phosphorus removal and recovery system (EBP2R) connected to a photobioreactor. Based on a simulation of a full-scale nutrient and water recovery system in its potential operating environment, we assess the potential environmental impacts of such a system using the EASETECH model. In the simulation, recovered water and nutrients are used in scenarios of agricultural 
irrigation-fertilization and aquifer recharge. In these scenarios, TRENS reduces global warming up to $15 \%$ and marine eutrophication impacts up to $9 \%$ compared to conventional treatment. This is due to the recovery and reuse of nutrient resources, primarily nitrogen. The key environmental concerns obtained through the LCA are linked to increased human toxicity impacts from the chosen end use of wastewater recovery products. The toxicity impacts are from both heavy metals release associated with land application of recovered nutrients and production of $\mathrm{AlCl}_{3}$, which is required for advanced wastewater treatment prior to aquifer recharge. Perturbation analysis of the LCA pinpointed nutrient substitution and heavy metals content of algae biofertilizer as critical areas for further research if the performance of nutrient recovery systems such as TRENS is to be better characterized. Our study provides valuable feedback to the TRENS developers and identified the importance of system expansion to include impacts outside the immediate nutrient recovery system itself. The study also showed for the first time the successful evaluation of urban-toagricultural water systems in EASETECH.

\section{Introduction}

Sustainability in the urban water cycle is increasingly at the forefront of discussions on new treatment technologies due changes in climate, population, and regulation (Guest et al., 2009). Wastewater resource recovery and reuse is one area where technology is responding to the need for pollution prevention and resource efficiency. Wastewater (also referred to as used water - Verstraete et al., 2009) technology development has traditionally been compliance-driven, designed to meet safety and discharge regulations. During conventional treatment, nutrients - notably nitrogen and phosphorus - are biologically and physicalchemically converted and removed from the water. Increasingly, the freshwater and nutrient content of wastewater are recognized as resources that can be recovered to address existing environmental concerns (e.g. water scarcity, use of non-renewable phosphorus) (Guest et al., 2009). However, resource recovery may come at the cost of increased treatment intensity and there is a need to assess treatment systems from a holistic systems perspective so that the quest for sustainability in the water cycle does not overshadow other environmental concerns (Mo \& Zhang, 2013, Batstone et al., 2014). 
TRENS is a wastewater resources recovery technology currently under development (Valverde-Pérez et al., 2015b), which combines an enhanced biological phosphorous removal and recovery (EBP2R) system (Valverde-Pérez et al., 2015) with a downstream photobioreactor (PBR) to cultivate green microalgae under optimal growth conditions. The system recovers both water and nutrient resources from wastewater, with the nutrients being taken up and encapsulated by the algal biomass. This water and algae suspension can then be used together (for combined irrigation and fertilization, otherwise referred to as fertigation) or individually if the algae are harvested through solid-liquid separation. The coupled system is a completely biological process that is less chemical and energy intensive than conventional physical-chemical phosphorus removal processes - e.g. struvite precipitation, ultrafiltration (Valverde-Pérez et al., 2015), thereby reducing the water and energy demand of traditional algae cultivation (Clarens et al., 2010).

In recent years, Life Cycle Assessment (LCA) has been used in environmental assessment of urban water systems (Loubet et al., 2014), including wastewater specific studies (Corominas et al., 2013, Zang et al., 2015). Moreover, LCA has been used in understanding environmental trade-offs in optimizing specific treatment technologies such as ozonation (Rodríguez et al. 2012). Recent wastewater related LCA studies for technology development include coupled wastewater treatment for microalgae biofuel production (Rothermel et al., 2013) and nutrient removal and recovery from anaerobic digestion supernatant (RodriguezGarcia et al., 2014). Both of these studies report the need to expand the system boundaries to include the wastewater treatment plant (WWTP) when evaluating wastewater technologies and emphasize the need to consider options at a plant level rather than at a unit process level. One of the challenges of LCA is delineating the system boundary since they vary widely, with some studies limited to the WWTP and others encompassing the entire urban water system (Corominas et al., 2013, Zang et al., 2015). The environmental performance of WWTPs is largely dependent on effluent discharge and sludge application on land (Hospido et al., 2004, 2012, Foley et al., 2010), although plant performance can be affected by influent composition, plant size, and local climate (Lorenzo-Toja et al., 2015). Furthermore, the sludge and solids stream of wastewater treatment accumulates beneficial and problematic compounds (e.g. phosphorus and heavy metals) that need to be included in LCA (Yoshida et al., 2013). Therefore, any environmental assessment of 
a novel wastewater technology needs to include life cycle boundaries that encompass the end use of water and nutrients.

This is the first study related to LCA-supported technology development that accounts not only for the WWTP, but also the larger system, which includes the urban-rural water connection and end-use of recovered water and nutrients. This broader system boundary is particularly necessary in view of the development objectives of TRENS, which is to provide an efficient resource recovery technology. An LCA carried out in the early development phase of TRENS provides a diagnostic opportunity: a chance to identify environmental impacts that may be roadblocks to developing and marketing a sustainability-focused technology. Moreover, the LCA results become documentation for sustainability that can iteratively follow TRENS throughout its development, optimization, and ultimately implementation.

The study objectives are (1) to demonstrate the use of LCA in the early research and development phase of a new wastewater process by quantifying its environmental performance using accepted impact categories; (2) to provide a first assessment of the environmental impacts of the TRENS system and (3) to use LCA results to provide feedback for additional research by identifying further areas of interest and data needs. The TRENS performance is assessed in three scenarios based on the Lynetten WWTP in Copenhagen. The scenarios were chosen to ensure an evaluation that captures the necessary infrastructure additions, operational changes, and reuse options.

\section{Materials and Methods}

\subsection{Framing a context for water and nutrient recovery}

Copenhagen and its surrounding municipalities are supplied entirely by groundwater. HOFOR, the local water utility, supplies approximately 50 million $\mathrm{m}^{3}$ annually to 1 million residents in the area. A high percentage of Danish households (>85\%) are connected to the sewers, meaning a large portion of the distributed water resource can be recaptured (Hochstrat et al., 2005). The Lynetten WWTP serves a catchment area of $76 \mathrm{~km}^{2}$ of the central and North-East sections of Copenhagen (Flores-Alsina et al., 2014) 
and treated 59.3 million $\mathrm{m}^{3}$ in 2012 (Lynettefællesskabet I/S). In the existing Lynetten WWTP, the effluent is discharged and mixed into the sea water of Øresund. Through the treatment process, nitrogen resources in the wastewater are converted to free nitrogen gas and lost to the atmosphere, while phosphorus is lost to the sludge and subsequently incinerated. In the WWTP, excess phosphorus that is not taken up in the biologically process is removed through chemical precipitation using iron (III) chloride ( $\mathrm{FeCl} 3)$.

The groundwater resource surrounding Copenhagen is over-exploited due to abstraction for drinking water. Henriksen et al. (2008) reported an estimated deficit of 77 million $\mathrm{m}^{3} / \mathrm{year}$ for the Northern-Zealand area, which encompasses Copenhagen. However, the refinement in spatial resolution can change results of water stress evaluations by 10-53\% (Hybel et al., 2015). In this context, wastewater reuse presents a valid opportunity to ameliorate the local groundwater resource deficit related to the Northern-Zealand area. In particular, there is an opportunity to collect water from the high-use urban area and return it to the rural groundwater abstraction areas.

Regulatory standards of treated wastewater reuse for irrigation or aquifer recharge are not specifically addressed by existing European Union (EU) policies, although there is an on-going effort to identify appropriate policies and encourage reuse (EC, 2012). Treated wastewater is most commonly reused for nonpotable purposes such as irrigation of non-food crops or crops requiring further processing (Bixio et al., 2006). This restricted use is due partly to the public's perceived risks from wastewater and partly to the lack of formal regulatory frameworks (Bixio et al., 2005, Chen et al., 2012). The implications of water quality, and therefore treatment needs, for scenario design is presented in Section 2.3.

\subsection{TRENS process addition to existing WWTP}

The TRENS system was included in this study as a side-stream process, where a portion of the influent wastewater at the Lynetten WWTP was diverted, while the remainder passed through existing conventional treatment (Fig. 1). The new side-stream system was designed to treat $10 \%$ of WWTP influent flow, which is approximately 5.9 million $\mathrm{m}^{3} / \mathrm{yr}$ or $16247 \mathrm{~m}^{3} / \mathrm{d}$. This flow rate is in excess of the reported local agricultural demands for irrigation water (2.1 and 0.93 million $\mathrm{m}^{3} / \mathrm{yr}$ for Zealand and the Capital Region, respectively, 
covering $2561 \mathrm{~km}^{2}$ in total). However, it is possible that irrigation values are underestimated since the total is based on self-reported water use from only $22 \%$ of the farms surveyed, in addition to inferred values from the non-responders (EC, 2010). It was also assumed that crop selection and irrigation practices may increase to take advantage of the available supply of reuse water. The TRENS system was designed to produce a nitrogen to phosphorus ratio (N-to-P ratio) of 16 optimal for microalgae cultivation in the PBR (ValverdePérez et al, 2015b). The nutrient concentration in the TRENS water is $47 \mathrm{mg} / \mathrm{L} \mathrm{N}$ and $6.5 \mathrm{mg} / \mathrm{L} \mathrm{P}$, thereby recovering 9 and $8 \%$ respectively of the nitrogen and phosphorus load to the Lynetten WWTP.

\subsection{Scenario construction}

Although many reuse options exist for reclaimed water (i.e. reuse in urban cleaning, industrial applications, control of salt water intrusion), this study focuses on two reuse scenarios that were considered most applicable to the TRENS system and the Danish context (Table 1). First, agriculture is the second largest water use sector after urban use and would therefore be a logical recipient of TRENS effluent which contains both nutrients and water. Second, as groundwater is the main freshwater supply in Denmark, aquifer recharge is an obvious method to augment freshwater sources. In addition, both agricultural irrigation and aquifer recharge are common and well-documented options for wastewater reuse (Bixio et al., 2006, EEA, 2010). Although the two scenarios are modeled separately in this study, it is possible to consider them as complementary where fertigation and aquifer recharge could be used at the same time with various flow ratios or individually at different times of the year. These use combinations were not modeled in order to minimize the scenario complexity. Additionally, the two scenarios represent two extreme cases for nutrient reuse, one where the nutrients are recovered continuously and the other where no nutrients are recovered. For the agricultural fertigation scenario it is assumed that the nutrients and water must be used together. If TRENS is used to supply a crop with $300 \mathrm{~mm} /$ year of irrigation water, the average nutrient load would be approximately $140 \mathrm{~kg} / \mathrm{h}$ a for $\mathrm{N}$ and $20 \mathrm{~kg} / \mathrm{ha}$ for $\mathrm{P}$, similar to the nutrient needs for common Danish crops such as winter wheat (Olesen et al., 2009). Since the water and nutrients are used together, either the water demand or the nutrient demand will be met first depending on numerous factors such as crop type, farming 
148 practices, and local climate. In reality, fertilizer and water requirements may have large variations seasonally

149 and across crop types and this complexity is not captured in the scenario. This scenario makes a simplifying 150 assumption that fertilizer and water needs are constant throughout the year and TRENS operation continues

151 uninterrupted. In this scenario, TRENS water is not further treated for pathogen removal since irrigation is

152 not targeted at any specific crop and the potential need for further treatment would vary by crop (e.g. less

153 strict for biofuel production than for tomato production).

154 In the aquifer recharge scenario, the microalgae component is separated out and ultimately incinerated.

155 Although the nutrients are an integral portion of the TRENS system, the intention of this scenario is to 156 explore the water recovery and reuse aspect independent of the nutrients. Excluding nutrient recovery also results in a more conservative outcome since there are no environmental benefits from nutrient reuse. Due to

158 the lack of EU-specific policies on water quality for aquifer recharge, the technology-based Californian Title

15922 regulation was used to define additional treatment processes including: coagulation/flocculation,

160 sedimentation, filtration, and UV disinfection (Bixio et al., 2006).

161 From a TRENS perspective, the aquifer recharge scenario is possibly the least optimal way to operate the 162 system since the nutrients are not utilized. Together with fertigation, which is possibly the most optimal way

163 TRENS can be operated, these two scenarios form the operational "envelope" for a potential TRENS system.

164 Neither scenario is completely realistic, but gives a simplified view of possibilities.

The LCA is performed using EASETECH (DTU, Denmark), a model that allows handling of heterogeneous materials and tracking of flows at the substance level essential for evaluation of environmental technologies

168 (Clavreul et al., 2014). Although initially developed for waste management systems, EASETECH's ability to

169 handle mass and individual substance flows allows for detailed modelling of wastewater treatment systems

170 (Yoshida et al., 2014a). The study follows the four-phased, iterative approach defined by ISO (2006)

171 consisting of (1) goal and scope definition, (2) inventory analysis, (3) impact assessment, and (4) results 172 interpretation. 
The goal of the LCA is to quantify the environmental impacts of wastewater resource recovery and reuse in agricultural crops production and in aquifer recharge associated with the operation of Lynetten WWTP, located southeast of Copenhagen, Denmark. To that end, the boundaries of this study are defined as starting from the influent of the WWTP, and extend to cover the WWTP itself, the TRENS side-stream process, transportation of the treated water in a pressurized pipeline, and final end use (including any additional advanced treatment required). Construction and operating phases are included in the scope. However, endof-life phases for the WWTP and TRENS system are not included. Studies related to WWTPs (Foley et al, 2010) and water reuse (Ortiz et al., 2007, Tangsubkul et al., 2005) have reported that end-of-life phases contribute relatively little to overall impacts compared to the construction and operation phases. Within the operating phase, both direct emissions (e.g. gas and treated water effluent) and indirect emissions (e.g. derived from production of chemicals and power generation) are included. The functional unit is defined as 1 $\mathrm{m}^{3}$ of influent wastewater with the same composition as reported by Lynettefællesskabet I/S (2012), as the primary function of the WWTP system - with or without TRENS sidestream - is to maintain public health and environmental water quality, with fertigation and aquifer recharge as secondary benefits.

\subsubsection{Life cycle inventory}

Life cycling inventory (LCI) data was collected from operating reports for existing processes, databases, and model results. Background inventory data was obtained through the Ecoinvent LCA database that contains unit process data valid mainly for Swiss and European markets (Frischknecht et al., 2005). Where TRENS water is used for crop irrigation, the nutrients $\mathrm{N}$ and $\mathrm{P}$ contained in the microalgae are assumed to offset mineral fertilizer application and production. In this study, both $\mathrm{N}$ and $\mathrm{P}$ substitutability is assumed as 100\% based on algae fertilizer performance on seedlings as reported in Mulbry et al. (2005). It is further assumed that microalgal fertilizer would result in zero runoff and leaching, and would perform similarly to mineral fertilizer in terms of ammonia volatilization, and soil mineralization. This assumption is analyzed in section 3.2.6 as it is known to be an oversimplification from other applications of biomass to land (Yoshida, 2014c). Although promising, the use of algae as fertilizer is still under investigation, as the influence of algae 
199 harvesting and application methods on fertilizer stability, availability, and performance is still poorly 200 documented in literature (Shilton et al. 2012). Additionally, the substitution of organic mineral fertilizer 201 depends on factors such as soil property and application technique (Lundin et al., 2000).

202 An analysis was made regarding nutrient leaching from algae fertilizer on environmental performance by 203 increasing leaching of applied nutrient $\mathrm{N}$ and $\mathrm{P}$ to groundwater in the model from 0 to $10 \%$. This study 204 initially assumed an optimal PBR operation where all the nutrients would be encapsulated in algae biomass. 205 Thus, the model was run with zero nutrient leaching to groundwater. This meant, there was no adverse 206 environmental impact and this process could not be identified during contribution analysis. However, this 207 process is important to investigate because one of the key benefits of algae fertilizer is its expected reduction 208 of nutrient mobility. The leaching could occur if the nutrients sent to the PBR were not completely taken up 209 by the algae and some remained in the water phase when it is sent to the irrigation systems.

210 Electricity production was based on consumption of Danish specific electricity mix, which is predominantly 211 fossil-based and uses coal (46.6\%), natural gas (24.4\%), wind (12.4\%) and heavy fuel oil (10.2\%) as the 212 main sources (EC-JRC, 2002).

\subsubsection{Impact assessment}

214 This study uses the LCIA method recommended by the International Reference Life Cycle Data System 215 (ILCD) (EC-JRC, 2010), commonly referred to as ILCD 2011. This method was selected as it consists of 216 fourteen impact categories based on existing best practice. Human toxicity related impacts were assessed using USETox, which is included in ILCD 2011 as best-of-the-field. Nevertheless, USETox results, particularly for metals, should be interpreted with caution since there are still many uncertainties related to the characterization factors (e.g. degradation rate, exposure routes). Results are normalized using normalization factors from Blok et al. (2013) and presented in milli-person equivalents (mPE), where $1 \mathrm{mPE}$ represents one thousandths of an average European person's annual impact. 


\subsubsection{Contribution and perturbation analysis}

223 The approach recommended by Clavreul (2013) for uncertainty and sensitivity assessment is used as the 224 basis for the contribution and perturbation analysis. The goal is to systematically identify potential sources of uncertainty, while operating under data scarcity and limited resources to evaluate the large number of inputs in the LCA model. This approach takes advantage of the iterative nature of LCA and uses the initial results from LCIA. The following steps were performed:

1. The contribution analysis identified any process (e.g. WWTP operation or biogas collection) that contributed more than 5\% to any impact category. Then, the key parameters that collectively contribute to $>90 \%$ of the process impacts were identified (e.g. $\mathrm{N}_{2} \mathrm{O}$ emission during WWTP operation). The cutoff is arbitrary and assigned to constrain the number of parameters so that they can be evaluated in a limited time frame.

2. A perturbation analysis was performed whereby the parameters identified in step 1 were varied one at a time by $10 \%$ to gauge the sensitivity of the model output to the parameter input following the example of Yoshida et al. (2014a) and Clavreul et al. (2012). Parameter sensitivity was then evaluated using a sensitivity ratio (SR):

$$
S R=\frac{\frac{\Delta \text { results }}{\text { initial result }}}{\frac{\Delta \text { parameter }}{\text { initial parameter }}}
$$

3. The results were discussed to highlight the sensitive parameters. The limitation of the assessment is that it does not take into account the actual uncertainty of the parameters, only how sensitive the model is to these parameters. The benefit of this method is it allows refinement the number of parameters needed for further data collection when ultimately conducting an uncertainty analysis. 


\section{Results and discussion}

\subsection{Inventory}

A summary of the life cycle inventory results is presented in Table 2. More detail is available in the Supporting Information.

\subsection{Impact assessment}

\subsubsection{Scenario A Status quo}

In the life cycle impacts of the existing Lynetten WWTP, the two impact categories of ecotoxicity (ETox) and marine eutrophication (ME) are the highest at 3.1 and 1.0 mPE, respectively (Fig. 2). This is primarily due to the discharge of treated effluent to the sea (Fig. 3). Nitrate-nitrogen in the effluent contribute most to the ME category, while the heavy metals in the effluent (mainly zinc and copper) contribute to the ETox category. Global warming at $7.8 \times 10^{-2} \mathrm{mPE}(\mathrm{GWP})$ is the third highest category. The largest contributor to this impact is energy consumption during WWTP operation (67\%), followed by emissions of $\mathrm{N}_{2} \mathrm{O}$ to air during treatment (18\%), emissions during incineration (11\%), and leakage of methane during biogas collection from the anaerobic digester (4\%). Biogas combustion and subsequent use for district heating, results in an offset GWP of $-4.5 \%$.

The emissions related to sludge incineration and biogas combustion are also major contributors to several impact categories, such as acidification (AC), terrestrial eutrophication (TE), and photochemical oxidant formation $(\mathrm{POF})$. Nitrogen oxides $\left(\mathrm{NO}_{\mathrm{x}}\right)$ and sulfur-dioxide are the main compounds responsible in these categories. Deposition of nitrogen and sulfur from the atmosphere contributes to acidification. In addition to the acidifying effect, atmospheric deposition of nitrogen also contributes to terrestrial eutrophication (Jaworski et al., 1997, Jeffries and Marron, 1997). Both NOx and sulfur dioxide contribute to POF since they form ozone when exposed to sunlight, which ultimately contributes to urban smog (Derwent et al., 1998).

The results suggest that the status quo model provides a reasonable representation of a large, centralized WWTP consistent with other wastewater LCA studies. The WWTP electricity consumption is one of the 
main contributors to global warming and fossil resource depletion as reported in Corominas et al. (2013).

Our study also finds that discharge to sea (primarily nitrate-nitrogen) is another main source of impacts, consistent with results from Hospido et al. (2004). All impact categories except one are within the same order of magnitude as values obtained in an LCA study of the Avedøre WWTP in Copenhagen (Yoshida et al., 2014a). The exception is for ETox where our result is more than twenty times higher than the median value given by Yoshida et al. 2014a. One possible reason for the higher ETox value at Lynetten WWTP is that it discharged eight times the copper per $1 \mathrm{~m}^{3}$ of influent than Avedøre WWTP (Spildevandscenter Avedøre I/S, 2012, Lynettefællesskabet I/S, 2012).

\subsubsection{Scenario B Agricultural fertigation}

Implementation of Scenario B has predicted environmental impacts that are on the order of 0 to $0.2 \mathrm{mPE} / \mathrm{m}^{3}$ less than Scenario A. The small changes are partly due to the design of the side-stream system. Since only $10 \%$ of the influent water passes through the TRENS system, the impacts are dominated by the effects of $90 \%$ of the flow passing through the WWTP. In the fertigation scenario, the main WWTP processes (e.g. discharge to sea and WWTP operation) continue to contribute to the impacts (Fig. 3b and c compared to Fig. 3a). However, the use-on-land process now plays a large part in the toxicity impacts (ETox, HTc, and HTnc).

Fig. 4a shows that the largest changes, both positive and negative, occur in the ME, ETox, HTc and HTnc categories. Overall, the reduced impacts are a result of two main processes (Fig. 4b): (1) reduced flow through WWTP secondary treatment leading to less $\mathrm{N}_{2} \mathrm{O}$ emissions, and (2) offset mineral fertilizer production. Increases in environmental impacts are mainly due to four processes: (1) land application of algae suspension, (2) energy consumption of the TRENS system, (3) energy consumption of the pipeline, and (4) emissions from increased biogas combustion.

The largest change from the baseline $(+0.19 \mathrm{mPE},+290 \%)$ is in the human toxicity, non-cancer effects category (HTnc). This is almost entirely a result of heavy metals - primarily zinc and mercury - application to soil from the treated effluent. The other toxicity categories (ETox and HTc) are similarly affected by the 
heavy metals. The avoided production and application of mineral fertilizer (shown in Fig. 4 as fertilizer substitution) results in some savings in toxicity related impacts. This is because mining of commercial fertilizer ingredients such as phosphate rock brings with it the naturally occurring heavy metals, notably cadmium (Wilsenach et al., 2003). These metals then end up in the soil once the fertilizer is applied. The avoided mineral fertilizer production is also responsible for $1 \%-24 \%$ savings in other impact categories (GWP, AC, TE, POF and PM), since there is lower production and therefore lower emissions from the associated industrial processes. However, land application of the effluent results in a net toxicity increase.

There is a decrease in marine eutrophication from the baseline (-9.2e-2 $\mathrm{mPE},-9 \%)$, which is almost entirely (98\%) due to the avoided discharge of nitrate-nitrogen to the sea. The TRENS side-stream diverted flow that would otherwise have entered the recipient water body (Øresund). In addition, during the TRENS process, soluble nitrogen, which has the potential to contribute to surface runoff and leaching, is taken up and stored in algal biomass prior to land application. Global warming impacts are reduced by $15 \%$ (1.2e-2 mPE) due to lower emissions of $\mathrm{N}_{2} \mathrm{O}$ from the WWTP since the water diverted to TRENS does not undergo ammonia oxidation and denitrification, the main pathways for $\mathrm{N}_{2} \mathrm{O}$ production (Kampschreur et al., 2009).

\subsubsection{Scenario C Aquifer recharge}

The overall environmental performance of the aquifer recharge scenario is similar to that of the baseline, Scenario A (Fig. 5). Scenario C has reduced WWTP energy consumption, but increased in TRENS-related energy consumption resulting in a very minor net change in total energy use.

The ME impact category decreased 8.6e-2 $\mathrm{mPE}(9 \%)$ from the baseline as a result of avoided nitrate-nitrogen discharge due to diversion of the TRENS sidestream. The category with the largest percent increase is HTc $(26 \%, 3.6 \mathrm{e}-3 \mathrm{mPE})$ as a result of pre-infiltration treatment, specifically due to production of aluminum chlorite $\left(\mathrm{AlCl}_{3}\right)$ used in the flocculation step of the pre-infiltration treatment to separate algae from the water. The production phase produces emissions of hexavalent chromium, $\mathrm{Cr}$ (VI), and arsenic, both of which are highly toxic. Niero et al. (2014) noted in a WWTP study that $\mathrm{AlCl}_{3}$ production was one of the main processes contributing to ecotoxicity. Separation of the algae and water could also be achieved through 
centrifugation or direct filtration, although these methods are associated with their own negative environmental impacts related to high energy demand (Rothermel et al. 2013). All other impact categories show changes of less than 5\% from the baseline. In terms of the processes involved, biogas combustion is a major contributor to increases in terrestrial eutrophication (TE) and photochemical oxidant formation (POF) impact categories. This was a result of increased sludge, and associated biogas, production from the TRENS system, thereby increasing biogas combustion and combustion-source pollutants (e.g. NOx). When compared to Scenario B (fertigation), the lack of nutrient recovery for agricultural reuse in this scenario meant higher GWP (12\%), AC (18\%), TE (23\%), and POF (12\%). However, HTc and HTnc were 45\% and 290\% lower than in the fertigation scenario, which shows the difference in diverting the nutrient water suspension to land, versus just water.

Scenario C explored a reuse option that was at the extreme end for TRENS, since only the water is reused and none of the recovered nutrients are reused. Although the environmental benefits are less pronounced than in the fertigation scenario, there are still benefits in terms of the ME impact category. TRENS may be a valid option in situations where there is interest in both water reuse and reducing nitrate-nitrogen discharge.

\subsubsection{Relative importance of construction versus operation of the overall life cycle}

The WWTP related impacts (Fig. 6a) are dominated by the operating phase, while the TRENS (Fig. 6b) and pipeline (Fig. 6c) impacts were more equally shared between the construction and operating life cycle phases. Furthermore, several impacts categories (TE, ME, POF, ETox, HTc, and RD) which are dominated by the operating phase for the WWTP, are instead dominated by the construction phase for TRENS and the pipeline. These differences were due to the higher use of plastic materials, specifically LDPE and HDPE plastics, in construction of the PBR and pipeline. In addition, the shorter service life of the PBR (15 years compared to 30 years for the WWTP) meant the construction phase impacts are more prominent.

The results are consistent with reports from Machado et al. (2007) and Pasqualino et al. (2010) who considered the WWTP construction phase insignificant compared to the operating phase. In studies which reported the opposite, Corominas et al. (2013) noted that those were for low-tech, non-energy intensive 
processes which are not comparable to the Lynetten WWTP. In terms of PBR construction, Rothermel et al.

(2013) reported that LDPE plastic production contributed to increased eutrophication, as was observed in this study. Silva et al. (2013) also found that the choice of construction material (in their case PVC plastic) caused the majority of PBR construction impacts. Both sources recommended optimizing the use of plastics in PBR construction as a way to reduce environmental impacts. It should be noted that this study's choice to use LDPE, as a representative material for PBR construction, was based on Rothermel et al. (2013) and this choice explains that LDPE production contributes a large portion of the overall TRENS impacts. These results illustrate the variability of life cycle phase contributions to environmental impacts. The construction phase was not important when dealing with the WWTP. However, this assumption should not be extrapolated to apply to other systems such as the PBR and the pipeline, and the construction phase should always be considered as supported by other piped network studies for both drinking water (Sanjuan-Delmás et al., 2014) and sewers (Petit-Boix et al., 2014).

Other implications for technology developers and future implementation of TRENS are: i) for the TRENS system, addressing both the construction and operating life cycle phases could have environmental benefits since both phases contribute nearly equally to the environmental impacts; and ii) in Scenarios B and C, TRENS (construction and operation) caused $4.4 \%$ and $3.5 \%$ of the overall environmental impacts. This was for a side-stream TRENS system treating $10 \%$ of the total influent wastewater and this contribution should increase as the proportion of side-stream flow increases. These results are technology specific. Impact results would change if the algae production takes place in an open pond system, which has lower energy requirements, but also has drawbacks like high land use and lower productivity (Jorquera et al., 2010).

361 The contribution analysis shows that 10 of the 14 processes included in this study had a greater than $5 \%$ 362 contribution to one or more impact categories (Fig. 7). In some cases, the process was mainly controlled by 363 one parameter, while others were governed by multiple parameters. In all, 18 parameters were identified that govern the important processes (Fig. 8) out of the 100s of input parameters. For example, the process 
"biogas collection" is a contributor to the GWP impact category and the key parameter responsible is the percentage of methane leakage during collection. Another example is the "WWTP operation" process; its impacts to GWP are governed by WWTP energy use, $\mathrm{FeCl}_{2}$ use, and $\mathrm{NaOH}$ use, which collectively contribute to more than $90 \%$ of the impacts. The implication for technology developers is that, in addition to reducing the number of relevant processes and parameters, the contribution analysis reveals specific areas where a system like TRENS may be competitive (i.e. $\mathrm{FeCl}_{2}$ use can be reduced by switching from chemical precipitation to TRENS for phosphorous removal and recovery).

\subsubsection{Perturbation analysis}

The results of the perturbation analysis are plotted as SR for each impact category (Fig. 9), where a higher absolute value of SR means that the impacts category is more sensitive to that parameter. The results show that some parameters have impacts across a number of categories (e.g. WWTP energy use and sludge water content), while others are important only to certain categories (e.g. Zn discharge to sea in the Etox impact category).

Nitrogen and phosphorus can both lead to eutrophication of waterways - nitrogen primarily affects marine waters while phosphorus affects freshwater - resulting in phytoplankton blooms and subsequent depletion of dissolved oxygen necessary for other aquatic life (Stoate et al., 2001). When leaching of nitrogen to the groundwater was increased from 0 to $10 \%$ in the fertigation scenario, marine eutrophication increased by $5.5 \%$, with no change in all other categories. Increasing phosphorus leaching in the same scenario from 0 to $10 \%$ increased freshwater eutrophication by $3.5 \%$, with less than $0.2 \%$ change in all other categories. In reality, the concern lies with nitrogen leaching since phosphorus has limited mobility in soil (Stoate et al., 2001). These impact changes due to leaching are significant because algae fertilizer performance is still poorly documented (Shilton et al., 2012). The fertigation scenario showed a 9\% decrease in marine eutrophication under the assumption that nutrients are not lost from the farmland. This benefit may be lost if nutrient leaching is increased. 
390 The results of the base scenario, and the fertigation and aquifer recharge scenarios, show how crucial it is to 391 assess new technologies in a holistic systems perspective. In the base scenario, most of the impacts of the full 392 system are due to the WWTP, except for the impact categories ME and ETox. Conversely, in the fertigation 393 scenario, most of the impacts take place outside the WWTP, with direct WWTP impacts playing a role in 394 half of the impact categories. If the focus had been limited to the TRENS technology, which is the natural 395 focus of technology developers, these impacts would not have been recognized.

For the fertigation scenario, increased toxicity appears to overwhelm the environmental benefits. The impacts on eco- and human toxicity were primarily related to heavy metals application to soil, and specifically to zinc and mercury carried in the TRENS effluent. Hospido et al. (2004) also found these metals to be the main culprits of increased toxicity when wastewater sludge was applied to land. Tangsubkul et al. (2005) noted that increased impacts on terrestrial environments might be inevitable when selecting a technology that optimizes recycling of wastewater nutrients, due to the potentially higher metals loading associated with higher nutrient recovery and reuse. The same findings do not seem to apply for the aquifer recharge scenario. During aquifer recharge the metals are partitioned to the WWTP discharge and incinerator ashes where the toxic impact is lower. This highlights that the form and environmental compartment in which metals are found are crucial. Heavy metals in soil (e.g. zinc) are largely immobile as they are retained by sorption, thereby reducing the leaching and related toxic effects to ground- and freshwater bodies (Anderson and Christensen, 1998, Christensen et al., 2000). This suggests that a better understanding of fate and toxicity of metals in soil is needed in the toxicity impact assessment methods. The LCA thus also supports that future research should address the heavy metals removal efficiency and reduction strategies in the TRENS technology, to ensure sustainable wastewater recovery.

412 Using the perturbation analysis, and knowledge of how TRENS may be applied in full-scale, it is possible to 413 identify parameters which are both sensitive (large absolute value of SR) and subject to large epistemic 
fertilizer substitution" in multiple impact categories (GWP, AC, TE) and both are related to how much mineral fertilizer is offset through application of algae fertilizer. The higher SR for "N fertilizer substitution" reflects the fact that average nitrogen fertilizer use emits more GHGs (fossil based $\mathrm{CO}_{2}, \mathrm{~N}_{2} \mathrm{O}$ ) than phosphorus fertilizer production (Stoate et al., 2001), suggesting that providing a well-defined N substitution value is more critical than for $\mathrm{P}$ substitution. The substitution value is influenced by local soil type and application methods (Lundin et al., 2000), and is likely to have high uncertainty. ii) " $\mathrm{N}_{2} \mathrm{O}$ emissions to air" is a sensitive parameter for GWP impact category associated with high uncertainty because it is influenced by many factors such as internal recycle rates, aeration efficiency, temperature, influent nitrogen loading, and sampling challenges (Yoshida et al., 2014b). More critically for TRENS, the interest would be to characterize emissions during PBR operation since studies have shown $\mathrm{N}_{2} \mathrm{O}$ production during algae cultivation (Guieysse et al., 2013). These results identified " $\mathrm{N}$ fertilizer substitution" and " $\mathrm{N}_{2} \mathrm{O}$ emissions" as priority parameters for the future development of TRENS and similar nutrient recovery processes in terms of data collection, laboratory testing, and modeling work.

\section{Conclusion}

Our study has shown the beneficial use of applying a mass and substance centered LCA model, EASETECH, in the early stage development of a new wastewater resource recovery technology. The main conclusions are:

- Assessing the true performance potential requires considering the consequences of a full-scale system placed into a specific local geographical context, water demand, and existing WWTP operations. Relative to status quo, TRENS was shown to reduce impacts by up to $15 \%$ for global warming and 9\% for marine eutrophication. High environmental impacts were associated with ecoand human toxicity categories as a result of the selected end uses of TRENS products, emphasizing the need for system expansion beyond the water and resource recovery technology itself.

- TRENS primarily improves WWTP performance by reducing nitrogen species in the effluent and direct nitrogen $\mathrm{N}_{2} \mathrm{O}$ emissions in the nitrification-denitrification process. 
- The TRENS system benefits are restricted by the limited need for freshwater substitution and fertilizer needs in the model area, but would increase proportionally with increased demand for resource substitution.

- The LCA identifies both construction and operation life cycle impacts as areas for improvement, particularly in PBR design, contrary to the operation life cycle focus assumed for conventional WWTPs.

- Finally, the LCA results provided feedback to technology developers and specifically TRENS developers by highlighting subcomponents that warrant better characterization (e.g. $\mathrm{N}_{2} \mathrm{O}$ emissions during PBR operation) or evaluation of technology options (e.g. algae cultivation using closed PBR

Ongoing development is focused on laboratory studies and modeling of the biological treatment system. However, decision-making and implementation benefits from a broader perspective even in the initial stages of development.

\section{ACKNOWLEDGEMENTS}

B. Valverde-Pérez acknowledges the financial support provided by the Integrated Water Technology (InWaTech) project - a research collaboration between the Technical University of Denmark and the Korean Advanced Institute of Science and Technology (DTU-KAIST, http://www.inwatech. org.www6.sitecore.dtu.dk). 
457

458

459

460

461

462

463

464

465

466

467

468

469

470

471

472

473

474

475

476

477

\section{References}

Anderson, P. R., Christensen, T. H., 1988. Distribution coefficients of Cd, Co, Ni, and $\mathrm{Zn}$ in soils. European Journal of Soil Science, 39(1), 15-22. doi: 10.1111/j.1365-2389.1988.tb01190.x

Batstone, D. J., Hülsen, T., Mehta, C. M., Keller, J., 2014. Platforms for energy and nutrient recovery from domestic wastewater: A review. Chemosphere, 140, 2-11. doi:10.1016/j.chemosphere.2014.10.021

Bixio, D., Cikurel, H., Muston, M., Miska, V., Joksimovic, D., Ravazzini, A., Aharoni, A., Savic, D., Thoeye, C., 2005. Municipal wastewater reclamation: where do we stand? An overview of treatment technology and management practice. Water Science \& Technology, 5(1), 77-86.

Bixio, D., Thoeye, C., De Koning, J., Joksimovic, D., Savic, D., Wintgens, T., Melin, T., 2006. Wastewater reuse in Europe. Desalination, 187(1-3), 89-101. doi:10.1016/j.desal.2005.04.070

Blok, K., Huijbregts, M., Roes, L., van Haaster, B., Patel, M., Hertwich, E., Hauschild, M., Sellke, P., Antunes, P., Hellweg, S., Ciroth, A., Harmelink, M., 2013. Development and application of a standardized methodology for the PROspective SUstaInability assessment of TEchnologies (PROSUITE). Report prepared within the EC 7th Framework Project, no: 227078

Chen, Z., Ngo, H. H., \& Guo, W., 2012. A critical review on sustainability assessment of recycled water schemes. Science of the Total Environment, 426, 13-31. doi:10.1016/j.scitotenv.2012.03.055

Christensen, T. H., Astrup, T., Boddum, J. K., Hansen, B. Ø., Redemann, S., 2000. Copper and zinc distribution coefficients for sandy aquifer materials. Water Research, 34, 709-712.

Clarens, A. F., Resurreccion, E. P., White, M. A, Colosi, L. M., 2010. Environmental life cycle comparison of algae to other bioenergy feedstocks. Environmental Science \& Technology, 44(5), 1813-1819. doi:10.1021/es902838n 
478 Clavreul, J., Guyonnet, D., Christensen, T. H., 2012. Quantifying uncertainty in LCA-modelling of waste 479 management systems. Waste Management, 32(12), 2482-2495. doi:10.1016/j.wasman.2012.07.008

480 Clavreul, J., 2013. LCA of waste management systems: Development of tools for modelling and uncertainty 481 analysis. PhD thesis. Technical University of Denmark. Kgs. Lyngby, Denmark.

482 Clavreul, J., Baumeister, H., Christensen, T. H., Damgaard, A., 2014. An environmental assessment system 483 for environmental technologies. Environmental Modelling \& Software, 60, 18-30. 484 doi:10.1016/j.envsoft.2014.06.007

485 Corominas, Ll., Foley, J., Guest, J. S., Hospido, A., Larsen, H. F., Morera, S., Shaw, A., 2013. Life cycle 486 assessment applied to wastewater treatment: state of the art. Water Research, 47(15), 5480-5492. 487 doi:10.1016/j.watres.2013.06.049

488 Derwent, R. G., Jenkin, M. E., Saunders, S. M., Pilling, M. J., 1998. Photochemical ozone creation potentials 489 for organic compounds in northwest Europe calculated with a master chemical mechanism. Atmospheric 490 Environment, 32(14-15), 2429-2441. doi:10.1016/S1352-2310(98)00053-3

491 European Commission (EC), 2010. Agricultural census in Denmark. http://ec.europa.eu/eurostat/statistics492 explained/index.php/Agricultural_census_in_Denmark

493 European Commission (EC), 2012. A Blueprint to Safeguard Europe's Water Resources. http://eur494 lex.europa.eu/legal-content/EN/TXT/PDF/?uri=CELEX:52012DC0673\&from=EN

495 European Commission - Joint Research Centre - Institute for Environment and Sustainability (EC-JRC), 496 2010. International Reference Life Cycle Data System (ILCD) Handbook - General guide for Life Cycle 497 Assessment - Detailed guidance. First edition March 2010. EUR 24708 EN. Luxembourg. Publications 498 Office of the European Union. 
499 European Commission - Joint Research Centre - Institute for Environment and Sustainability (EC-JRC), 500 2002. European Reference Life Cycle Database ELCD Database version 2.0. DK Electricity Mix, AC, 501 consumption mix, at consumer, 230V.

502 European Environment Agency (EEA), 2010. The European Environment - State and Outlook 2010.

503 Technical report, European Environment Agency, Copenhagen.

504 Flores-Alsina X., Gernaey K.V. Jeppsson U., 2012. Benchmarking biological nutrient removal in wastewater 505 treatment plants: influence of mathematical model assumptions. Water Science \& Technology, 65 (8), 1496506 1505. doi:10.2166/wst.2012.039

507 Flores-Alsina, X., Saagi, R., Lindblom, E., Thirsing, C., Thornberg, D., Gernaey, K. V, Jeppsson, U., 2014. 508 Calibration and validation of a phenomenological influent pollutant disturbance scenario generator using 509 full-scale data. Water Research, 51, 172-185. doi:10.1016/j.watres.2013.10.022

510 Foley, J., de Haas, D., Hartley, K., Lant, P., 2010. Comprehensive life cycle inventories of alternative 511 wastewater treatment systems. Water Research, 44(5), 1654-1666. doi:10.1016/j.watres.2009.11.031

512 Frischknecht, R., Jungbluth, N., Althaus, H., Doka, G., Dones, R., Heck, T., Hellweg, S., Hischier, R., 513 Nemecek, T., Rebitzer, G., Spielmann, M., 2005. The Ecoinvent Database: Overview and Methodological 514 Framework. International Journal of Life Cycle Assessment, 10(1), 3-9. doi:10.1065/lca2004.10.181.1

515 Guest, J. S., Barnard, J. L., Beck, B. M., Daigger, G. T., Hilger, H., Jackson, S. J., 2009. A New Planning 516 and Design Paradigm to Achieve Sustainable Resource Recovery from Wastewater. Environmental Science 517 \& Technology, 43(16), 6121-6125. doi:10.1021/es803001r

518 Gernaey, K.V., Jeppsson, U., Vanrolleghem, P.A., Copp, J.B., 2014. Benchmarking of Control Strategies for 519 Wastewater Treatment Plants. IWA Scientific and Technical Report No. 23. London, UK: IWA Publishing. 
520 Guieysse, B., Plouviez, M., Coilhac, M., Cazali, L., 2013. Nitrous Oxide (N2O) production in axenic

521 Chlorella vulgaris microalgae cultures: evidence, putative pathways, and potential environmental impacts.

Biogeosciences, 10(10), 6737-6746. doi:10.5194/bg-10-6737-2013

523 Henriksen, H. J., Troldborg, L., Højberg, A. L., Refsgaard, J. C., 2008. Assessment of exploitable

524 groundwater resources of Denmark by use of ensemble resource indicators and a numerical groundwatersurface water model. Journal of Hydrology, 348(1-2), 224-240. doi:10.1016/j.jhydrol.2007.09.056

Henze, M., Gujer, W., Mino, T., Matsuo, T., Van Loosdrecht, M. C. M., 2000. Activated Sludge Models ASM1, ASM2, ASM2d and ASM3. London: IWA Publishing.

Hochstrat, R., Wintgens, T., Melin, T., Jeffrey, P., 2005. Wastewater reclamation and reuse in Europe: a model-based potential estimation. Water Science \& Technology, 5(1), 67-76.

Hospido, A., Moreira, M. T., Fernandez-Couto, M., Feijoo, G., 2004. Municipal Wastewater Treatment

531 Plant, LCA Case Studies, Environmental Performance of a Municipal Wastewater Treatment Plant.

532 International Journal of Life Cycle Assessment, 9(4), 261-271. doi:10.1007/bf02978602 groundwaterbased water supply on freshwater resources. Journal of Environmental Management, 160, 90- 
541 Jaworski, N. a., Howarth, R. W., Hetling, L. J., 1997. Atmospheric Deposition of Nitrogen Oxides onto the 542 Landscape Contributes to Coastal Eutrophication in the Northeast United States. Environmental Science \& Technology, 31(7), 1995-2004. doi:10.1021/es960803f

544 Jefferies, R. L., Maron, J. L., 1997. The embarrassment of riches: atmospheric deposition of nitrogen and 545 community and ecosystem processes. Trends in Ecology and Evolution, 12(2), 74-78. doi:10.1016/S0169$546 \quad 5347(96) 20125-9$

547 Jorquera, O., Kiperstok, A., Sales, E. a, Embiruçu, M., Ghirardi, M. L., 2010. Comparative energy life-cycle 548 analyses of microalgal biomass production in open ponds and photobioreactors. Bioresource Technology, 549 101(4), 1406-1413. doi:10.1016/j.biortech.2009.09.038

550 Kampschreur, M. J., Temmink, H., Kleerebezem, R., Jetten, M. S. M., van Loosdrecht, M. C. M., 2009. 551 Nitrous oxide emission during wastewater treatment. Water Research, 43(17), 4093-4103. 552 doi:10.1016/j.watres.2009.03.001

553 Københavns Energi, 2001. Arrenæs kunstig infiltration af Arresøvand - Afrapportering 2000 (English: 554 Arrenæs artificial infiltration of Lake Arresø water - Operating report 2000). efficiency analysis of Spanish WWTPs using the LCA + DEA method. Water Research, 68, 651-666. doi:10.1016/j.watres.2014.10.040

Loubet, P., Roux, P., Loiseau, E., Bellon-Maurel, V., 2014. Life cycle assessments of urban water systems: 559 A comparative analysis of selected peer-reviewed literature, Water Research, 67, 187-202. 560 doi:10.1016/j.watres.2014.08.048

561 Lundin, M., Bengtsson, M., Molander, S., 2000. Life Cycle Assessment of Wastewater Systems: Influence of 562 System Boundaries and Scale on Calculated Environmental Loads. Environmental Science \& Technology, 563 34(1), 180-186. doi:10.1021/es990003f 
564 Lundin, M., Olofsson, M., Pettersson, G. J., Zetterlund, H., 2004. Environmental and economic assessment 565 of sewage sludge handling options. Resources, Conservation and Recycling, 41(4), 255-278.

566 doi:10.1016/j.resconrec.2003.10.006

567 Lynettefællesskabet I/S, 2012. Miljøberetning 2012 (English: Environmental Report 2012).

568 Machado, A. P., Urbano, L., Brito, A. G., Janknecht, P., Salas, J. J., Nogueira, R., 2007. Life cycle 569 assessment of wastewater treatment options for small and decentralized communities. Water Science \& 570 Technology, 56(3), 15-22. doi:10.2166/wst.2007.497

571 Mo, W., Zhang, Q., 2013. Energy-nutrients-water nexus: integrated resource recovery in municipal 572 wastewater treatment plants. Journal of Environmental Management, 127, 255-267.

573 doi:10.1016/j.jenvman.2013.05.007

574 Mulbry, W., Westhead, E. K., Pizarro, C., Sikora, L., 2005. Recycling of manure nutrients: use of algal 575 biomass from dairy manure treatment as a slow release fertilizer. Bioresource Technology, 96(4), 451-458. 576 doi:10.1016/j.biortech.2004.05.026

577 Niero, M., Pizzol, M., Bruun, H. G., Thomsen, M., 2014. Comparative life cycle assessment of wastewater 578 treatment in Denmark including sensitivity and uncertainty analysis. Journal of Cleaner Production, 68, 25$579 \quad$ 35. doi: $10.1016 / j . j c l e p r o .2013 .12 .051$

580 Olesen, J. E., Askegaard, M., Rasmussen, I. A., 2009. Winter cereal yields as affected by animal manure and 581 green manure in organic arable farming. European Journal of Agronomy, 30(2), 119-128.

582 doi:10.1016/j.eja.2008.08.002

583 Ortiz, M., Raluy, R. G., Serra, L., 2007. Life cycle assessment of water treatment technologies: wastewater 584 and water-reuse in a small town. Desalination, 204(1-3), 121-131. doi:10.1016/j.desal.2006.04.026

585 Pasqualino, J. C., Meneses, M., Castells, F., 2010. Life Cycle Assessment of Urban Wastewater Reclamation 586 and Reuse Alternatives. Journal of Industrial Ecology, 15(1), 49-63. doi:10.1111/j.1530-9290.2010.00293.x 
587 Petit-Boix, A., Sanjuan-Delmás, D., Gasol, C. M., Villalba, G., Suárez-Ojeda, M. E., Gabarrell, X., Josa, A., 588 Rieradevall, J., 2014. Environmental Assessment of Sewer Construction in Small to Medium Sized Cities 589 Using Life Cycle Assessment. Water Resources Management, 28(4), 979-997. doi:10.1007/s11269-014$590 \quad 0528-\mathrm{Z}$

591 Rodríguez, A., Muñoz, I., Perdigón-Melón, J. A, Carbajo, J. B., Martínez, M. J., Fernández-Alba, A. R., 592 García-Calvo, E., Rosal, R., 2012. Environmental optimization of continuous flow ozonation for urban 593 wastewater reclamation. Science of the Total Environment, 437, 68-75. doi:10.1016/j.scitotenv.2012.07.084 594 Rodriguez-Garcia, G., Frison, N., Vázquez-Padín, J. R., Hospido, A., Garrido, J. M., Fatone, F., Bolzonella, 595 D., Moreira, M.T., Feijoo, G., 2014. Life cycle assessment of nutrient removal technologies for the treatment 596 of anaerobic digestion supernatant and its integration in a wastewater treatment plant. Science of the Total Environment, 490C, 871-879. doi:10.1016/j.scitotenv.2014.05.077

Rothermel, M. C., Landis, A. E., Barr, W. J., Soratana, K., Reddington, K. M., Weschler, M. K., Witter, G., 599 Harper, W. F., 2013. A Life Cycle Assessment Based Evaluation of a Coupled Wastewater Treatment and 600 Biofuel Production Paradigm. Journal of Environmental Protection, 4(9), 1018-1033.

601 doi:10.4236/jep.2013.49118

Sanjuan-Delmás, D., Petit-Boix, A., Gasol, C. M., Villalba, G., Suárez-Ojeda, M. E., Gabarrell, X., Josa, A., Rieradevall, J., 2014. Environmental assessment of different pipelines for drinking water transport and distribution network in small to medium cities: A case from Betanzos, Spain. Journal of Cleaner Production, 66, 588-598. doi:10.1016/j.jclepro.2013.10.055

Shilton, A. N., Powell, N., and Guieysse, B., 2012. Plant based phosphorus recovery from wastewater via algae and macrophytes. Current Opinion in Biotechnology, 23(6), 884-889. doi:10.1016/j.copbio.2012.07.002 
609 Silva, A. G., Carter, R., Merss, F. L. M., Corrêa, D. O., Vargas, J. V. C., Mariano, A. B., Ordonez, J. C.,

610 Scherer, M. D., 2015. Life cycle assessment of biomass production in microalgae compact photobioreactors.

611 GCB Bioenergy, 7(2), 184-194. doi:10.1111/gcbb.12120

612 Spildevandscenter Avedøre I/S, 2012. Miljøredegørelse 2012 (English: Environmental Statement 2012).

613 Stoate, C., Boatman, N. D., Borralho, R. J, Rio Carvalho, C., de Snoo, G. R., Eden, P., 2001. Ecological

614 impacts of arable intensification in Europe. Journal of Environmental Management, 63(4), 337-365.

615 doi:10.1006/jema.2001.0473

616 Tangsubkul, N., Beavis, P., Moore, S. J., Lundie, S., Waite, T. D., 2005. Life cycle assessment of water 617 recycling technology. Water Resources Management, 19, 521-537. doi: 10.1007/s11269-005-5602-0

618 Valverde-Pérez, B., Wágner, D. S., Sæbø, M., Van Wagenen, J., Angelidaki, I., Smets, B. F., Plósz, B. G., 619 2014. An activated sludge model for mixed green micro-algae (ASM-A) - Model development and 620 evaluation using the case of resource recovery. 4th IWA/WEF Wastewater Treatment Modelling Seminar 6212014, Spa.

622 Valverde-Pérez, B., Ramin, E., Smets, B. F., Plósz, B. G., 2015. EBP2R - An innovative enhanced 623 biological nutrient recovery activated sludge system to produce growth medium for green microalgae 624 cultivation. Water Research, 68, 821-830. doi:10.1016/j.watres.2014.09.027

625 Valverde-Pérez, B., Fuentes-Martínez, J.M., Flores-Alsina, X., Gernaey, K.V., Huusom, J.K., Plósz, B.G., 626 2015b. Control structure design of an innovative enhanced biological nutrient recovery activated sludge 627 system coupled with a photbioreactor. Computer Aided Chemical Engineering, 37, 2555-2560.

628 Venkatesh, G., Hammervold, J., Brattebø, H., 2009. Combined MFA-LCA for Analysis of Wastewater 629 Pipeline Networks. Journal of Industrial Ecology, 13(4), 532-550. doi:10.1111/j.1530-9290.2009.00143.x

630 Verstraete, W., Van de Caveye, P., Diamantis, V., 2009. Maximum use of resources present in domestic 631 "used water". Bioresource Technology, 100(23), 5537-5545. doi:10.1016/j.biortech.2009.05.047 
632 Wilsenach, J. A, Maurer, M., Larsen, T. A, van Loosdrecht, M. C. M., 2003. From waste treatment to 633 integrated resource management. Water Science and Technology, 48(1), 1-9.

634 Yoshida, H., Christensen, T. H., Scheutz, C., 2013. Life cycle assessment of sewage sludge management: A 635 review. Waste Management \& Research, 31(11), 1083-1101. doi:10.1177/0734242X13504446

636 Yoshida, H., Clavreul, J., Scheutz, C., Christensen, T. H., 2014a. Influence of data collection schemes on the 637 Life Cycle Assessment of a municipal wastewater treatment plant. Water Research, 56, 292-303. 638 doi:10.1016/j.watres.2014.03.014

639 Yoshida, H., Mønster, J., Scheutz, C., 2014b. Plant-integrated measurement of greenhouse gas emissions 640 from a municipal wastewater treatment plant. Water Research, 61, 108-118.

641 doi:10.1016/j.watres.2014.05.014

642 Yoshida, H., Scheutz, C., Christensen, T. H., 2014c, Life cycle assessment of sewage sludge treatment and 643 its use on land. PhD thesis, Technical University of Denmark. Lyngby, Denmark.

644 Zang, Y., Li, Y., Wang, C., Zhang, W., and Xiong, W., 2015. Towards more accurate life cycle assessment 645 of biological wastewater treatment plants: a review. Journal of Cleaner Production.

646 doi:10.1016/j.jclepro.2015.05.060 
Table 1: Operational scenarios for TRENS implementation in the Copenhagen area, Denmark

Table 2: LCI sources and results summary. X denotes where operation and construction is included.

650 Complete datasets are available in the Supporting Information.

651 Figure 1: Flow diagram of TRENS system (EBP2R and downstream PBR) implemented as sidestream 652 process to the existing Lynetten WWTP. Figure created from TRENS (Valverde-Pérez et al., 2014; 653 Valverde-Pérez et al., 2015) and Lynetten process flow diagrams (Lynettefællesskabet I/S, 2012). Solid lines 654 show flow of water, dotted lines show sludge or solids flow.

Figure 2: Normalized LCIA impact results are dominated by marine eutrophication and ecotoxicity. Impact categories abbreviations: Global warming potential (GWP), terrestrial acidification (AC), terrestrial eutrophication (TE), marine eutrophication (ME), ecotoxicity (ETox), human toxicity - cancer effects (HTc), human toxicity - non-cancer effects (HTnc), particulate matter (PM), resource depletion - fossil (RD).

Figure 3: Percent contribution of individual processes each impact category for the three operating scenarios (a) status quo, (b) fertigation, and (c) aquifer recharge. The life cycle phases of construction and operation are shown separately for the WWTP, but combined for other processes (e.g. TRENS, pipeline). Refer to Fig. 2 for abbreviations.

Figure 4: Environmental performance of fertigation with TRENS relative to baseline scenario (a) and the individual processes that contribute to the change (b). The left plot provides the magnitude of change, while the right plot provides the reasons for that change. The percentage contribution plot is scaled such that the sum of all processes is $100 \%$. Refer to Fig. 2 for abbreviations.

Figure 5: Environmental performance of aquifer recharge with TRENS relative to baseline scenario (left) 
669 Figure 6: Relative contributions of construction and operation phase impacts in the B: fertigation scenario 670 results for (a) the WWTP, (b) TRENS system and (c) pipeline. WWTP impacts are dominated by operation 671 energy consumption, while TRENS and pipeline are more influenced by materials (plastics) used in the 672 construction phase. Refer to Fig. 2 for abbreviations.

673 Figure 7: Contribution of processes to individual impact categories. Any process with a colored block 674 indicates it contributes $>5 \%$ to an impact category.

675 Figure 8: Key parameters identified from contribution analysis

676 Figure 9: Sensitivity ratios showing the change in model output relative to change in parameter input.

677 Negative SR indicates that model output responds in the opposite direction as parameter change (i.e. increase 678 in parameter means decrease in model output). 
1 Table 1: Operational scenarios for TRENS implementation in Copenhagen

\begin{tabular}{ll}
\hline A. & $\begin{array}{l}\text { Scenario of existing conventional system in Copenhagen, where wastewater is collected and treated at } \\
\text { Status quo }\end{array}$ \\
\hline $\begin{array}{l}\text { B. } \\
\text { Agricultural }\end{array}$ & $\begin{array}{l}\text { Scenario directly utilizes the TRENS system outputs (algal suspension) for fertigation. This scenario } \\
\text { involves diverting 10\% of the influent WWTP to the TRENS system and requires additional } \\
\text { fertigation } \\
\text { infrastructure and energy consumption. The remaining 90\% of the WWTP influent is treated in the } \\
\text { conventional system. Modified WWTP experiences increased sludge and biogas production due to } \\
\text { lower solids retention time (SRT) in the EBP2R system. Following the TRENS process, the water is } \\
\text { pumped to the end user through a 25 km pipeline. There is no treatment downstream of the PBR prior } \\
\text { to use in fertigation. The nutrients contained in the algae acts as a substitute for synthetic fertilizer. }\end{array}$ \\
\hline $\begin{array}{l}\text { C. } \\
\text { Aquifer } \\
\text { recharge }\end{array}$ & $\begin{array}{l}\text { Scenario requires the same modifications to the WWTP as in the agricultural reuse application. Algal } \\
\text { suspension downstream of the PBR is sent to tertiary treatment to separate the microalgae and water, } \\
\text { so that the water goes on to aquifer recharge basins and the algae biomass is sent to the WWTP for } \\
\text { dewatering, drying, and incineration. }\end{array}$ \\
\hline
\end{tabular}

Table 2: LCI sources and results summary. X marks where operation and construction is included. Complete datasets are available in Supporting Information.

\begin{tabular}{|c|c|c|c|c|}
\hline Process & Scenario & & $\begin{array}{c}\text { Opera } \\
\text {-tion }\end{array}$ & $\begin{array}{c}\text { Construc- } \\
\text { tion }\end{array}$ \\
\hline WWTP & $\mathrm{A}, \mathrm{B}, \mathrm{C}$ & $\begin{array}{l}\text { Site-specific data for the Lynetten WWTP was based on available public } \\
\text { reports from the local utility for the year } 2012 \text { (Lynettefællesskabet I/S, 2012). } \\
\text { WWTP infrastructure inventory estimated proportional to flow rate using Foley } \\
\text { et al. (2010). } \\
\text { The WWTP is a } 59.3 \text { million } \mathrm{m}^{3} / \text { year facility, including primary and secondary } \\
\text { treatment (BNR and phosphorus precipitation), anaerobic digestion, and } \\
\text { incineration. Energy consumption of } 0.51 \mathrm{kWh} / \mathrm{m}^{3} \text {. Anaerobic digester } \\
\text { operated with yield of } 70 \% \text { anaerobically degradable carbon to produce biogas } \\
\text { with } 60 \% \text { methane. Bulk of biogas sent to combustion for heat generation } \\
(89 \%) \text {, some lost in leaks }(3 \%) \text {, and remainder flared }(8 \%) \text {. Assumed lifetime is } \\
30 \text { years. }\end{array}$ & $X$ & $X$ \\
\hline TRENS & $\mathrm{B}, \mathrm{C}$ & $\begin{array}{l}\text { Well-established activated sludge models (ASM) were used for process design } \\
\text { and optimization (Henze et al., 2000). ASM-2d (Flores-Alsina et al., 2012) and } \\
\text { ASM-A (Valverde-Pérez et al., 2014) models used to simulate growth of } \\
\text { activated sludge bacteria in the EBP2R process and green micro-algae in the } \\
\text { PBR, respectively. Reactor sizing and operating of the EBP2R were based on } \\
\text { scenario analysis optimization as carried out in Valverde-Pérez et al. (2015), } \\
\text { while the PBR was designed according to Wágner et al. (2015). Energy usage } \\
\text { for EBP2R due to aeration, pumping and mixing was evaluated using the } \\
\text { Benchmark Simulation Model no. } 2 \text { (BSM2) guidelines (Gernaey et al., 2014). } \\
\text { The PBR construction impacts are represented by calculating the mass of low- } \\
\text { density polyethelene (LDPE) plastic needed to construct the horizontal reactor } \\
\text { panels (Rothermel et al., 2013). PBR operational energy was taken from } \\
\text { literature for closed, flat-panel PBRs (Jorquera et al., 2010). } \\
\text { Two anaerobic tanks ( } 680 \mathrm{~m}^{3} \text { each), one aerobic tank }\left(3150 \mathrm{~m}^{3}\right) \text { and a settler } \\
\text { were constructed. WWTP infrastructure inventory increased by } 2.6 \% \\
\text { proportional to increase in reactor volumes. Energy use of WWTP increases by } \\
0.12 \mathrm{kWh} / \mathrm{m}^{3} \text { due to EBP2R side-stream aeration, pumping, and mixing. } \\
\text { Sludge production increased by } 13 \% \text { due to lower solids retention time. Biogas } \\
\text { production increased proportionally to sludge production. PBR reactor of } \\
20,000 \mathrm{~m}^{3} \text { requiring } 0.015 \mathrm{~kg} \text { LDPE/m } \mathrm{m}^{3} \text { and } 0.14 \mathrm{kWh} / \mathrm{m}^{3} \text { influent. This system } \\
\text { has an } 80 \% \text { phosphorus recovery (combined for the EBP2R and PBR) and } \\
\text { produces effluent N-to-P ratio of } 17 \text { which is encapsulated in the algae. }\end{array}$ & $X$ & $X$ \\
\hline
\end{tabular}


Assumed lifetime is 15 years.

Operating energy calculated using Hazen-Williams headloss equation with pipe coefficient of 140 . The distribution pipeline construction inventory considered in this study is based on Venkatesh et al. (2009).

Pipeline $\quad$ B, C $\quad 25 \mathrm{~km}$ pipeline constructed consisting of two parallel pipes $0.579 \mathrm{~m}$ in diameter and $30 \mathrm{~m}$ elevation increase. Infrastructure inventory based on 2292 tons highdensity polyethylene (HDPE) required for pipe production and diesel fuel consumption during construction $(45 \mathrm{~L} / \mathrm{m})$. Operating energy consumption of $0.025 \mathrm{kWh} / \mathrm{m}^{3}$. Assumed lifetime is 30 years.

Existing equipment at farms is assumed used for irrigation, thus no additional infrastructure is included. Energy consumption for TRENS water irrigation is Irrigation $\quad \mathrm{B} \quad$ assumed comparable to existing groundwater-based system and small relative to energy required for long-distance distribution pumping. Nutrient content for fertilizer substitution is $4.6 \mathrm{mg} \mathrm{P} / \mathrm{L}$ and $33 \mathrm{mg} \mathrm{N} / \mathrm{L}$.

Pre-

infiltration

C

treatment

Infiltration

basin
Pre-treatment and algae harvesting prior to aquifer recharge scenario is based on tertiary treatment data from Pasqualino et al. (2010), which includes coagulation/flocculation, filtration, disinfection (UV and chlorination). Energy consumption is $0.021 \mathrm{kWh} / \mathrm{m}^{3}$.

$110000 \mathrm{~m}^{2}$ open basin design based on long-term average infiltration rate of 55 $\mathrm{m} / \mathrm{yr}$ (Københavns Energi, 2001) with water depth of $0.5 \mathrm{~m}$. Basin construction

C represented by excavation of $78,320 \mathrm{~m}^{3}$ by hydraulic digger. Infiltration is by gravity, so energy consumption is assumed negligible compared to other processes. Assumed lifetime is 30 years. 


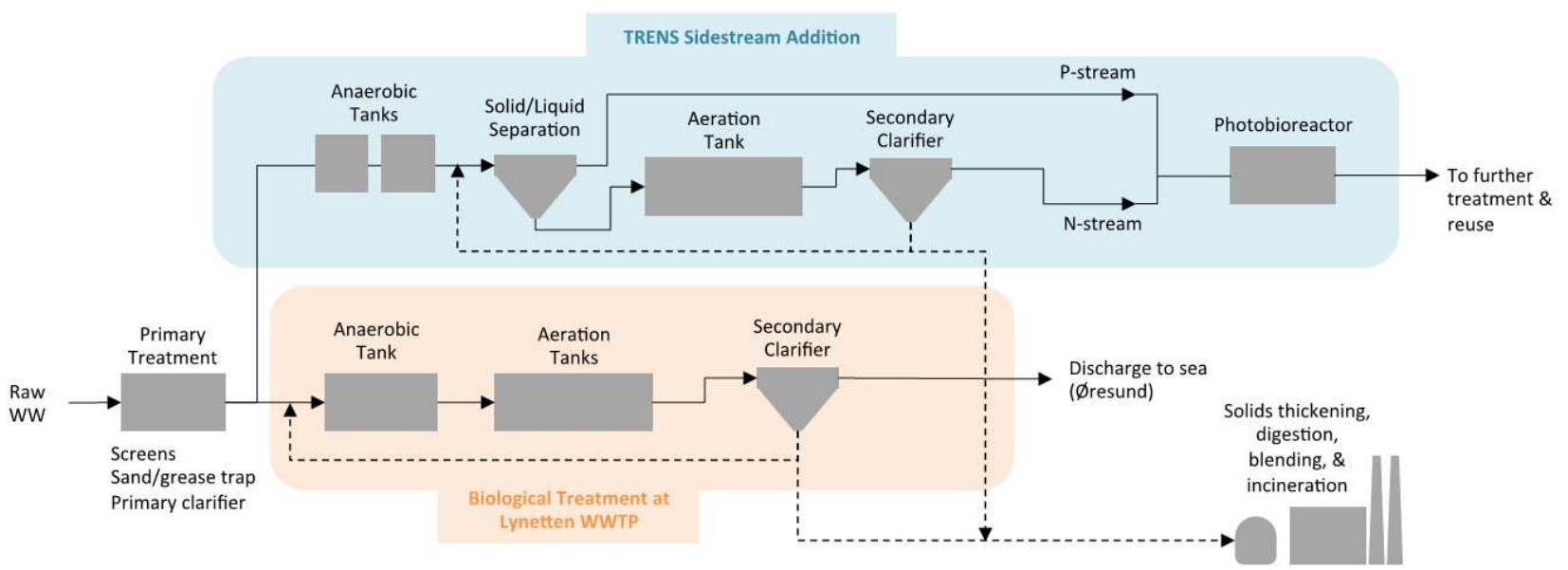

2 Figure 1: Flow diagram of TRENS system (EBP2R and downstream PBR) implemented as sidestream 3 process to the existing Lynetten WWTP. Figure created from TRENS (Valverde-Pérezet al., 2014; Valverde4 Pérezet al., 2015) and Lynetten process flow diagrams (Lynettefællesskabet I/S, 2012). Solid lines show flow 5 of water, dotted lines show sludge or solids flow. 


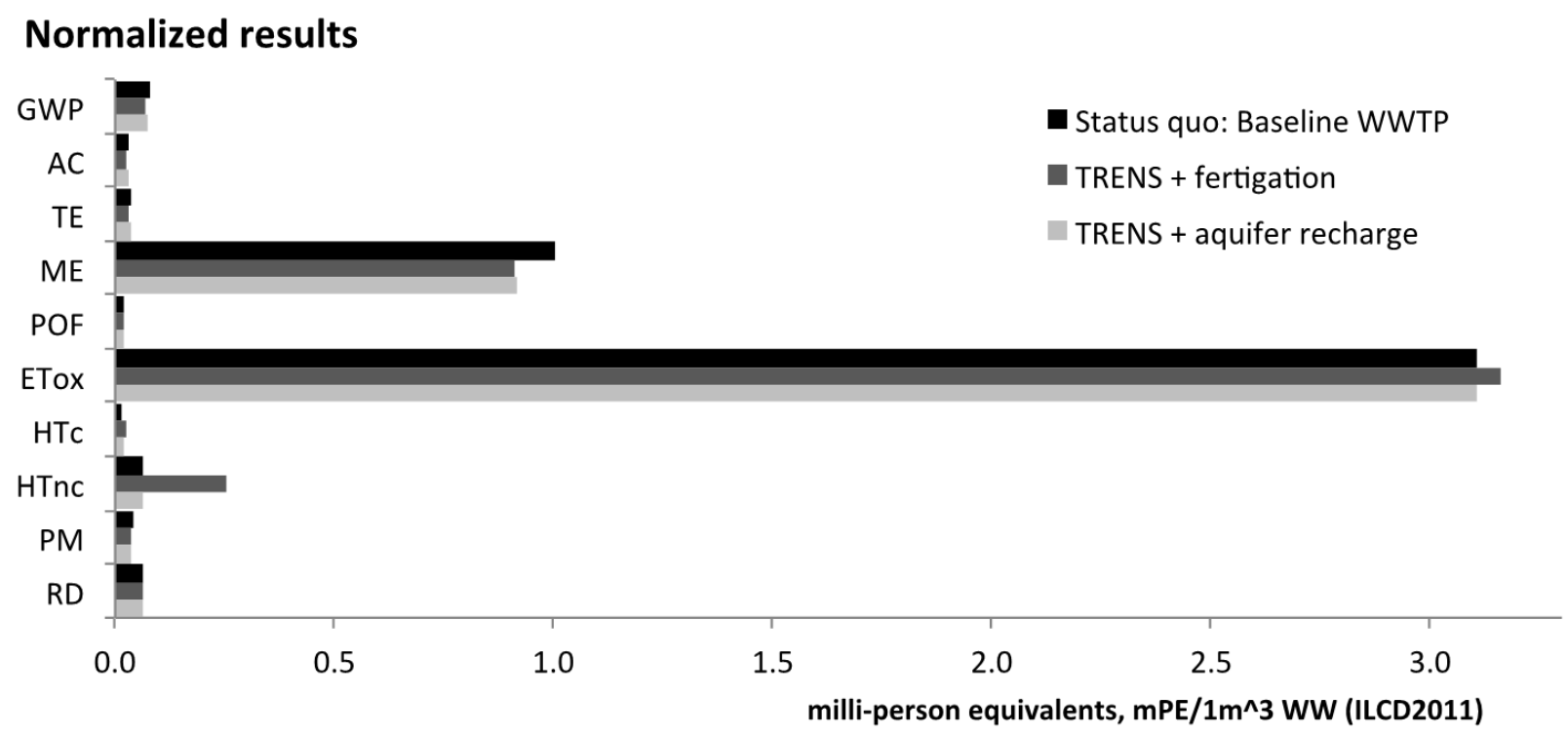

8 Figure 2: Normalized LCIA impact results are dominated by marine eutrophication and ecotoxicity. Impact 9 categories abbreviations: Global warming potential (GWP), terrestrial acidification (AC), terrestrial 10 eutrophication (TE), marine eutrophication (ME), ecotoxicity (ETox), human toxicity - cancer effects (HTc), 11 human toxicity - non-cancer effects (HTnc), particulate matter (PM), resource depletion - fossil (RD). 


\section{Status quo - Percent contribution}

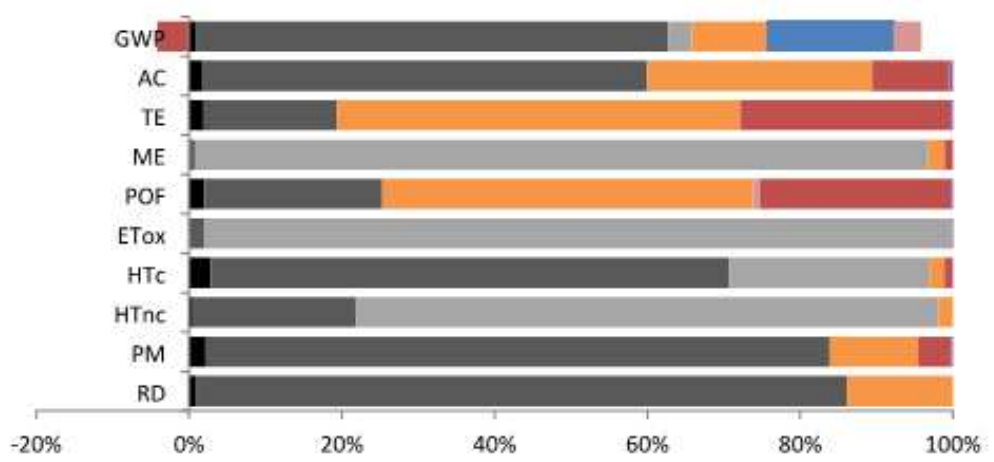

\section{TRENS + fertigation - Percent contribution}

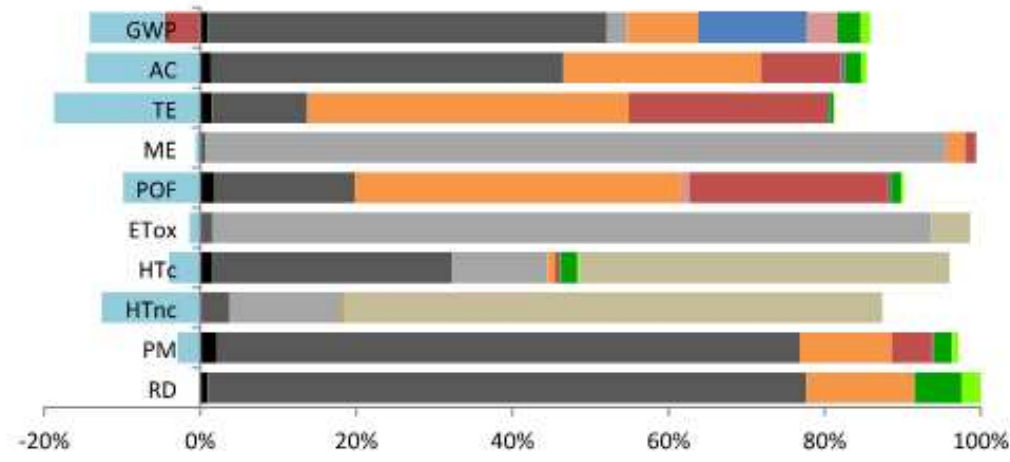

TRENS + aquifer recharge - Percent contribution

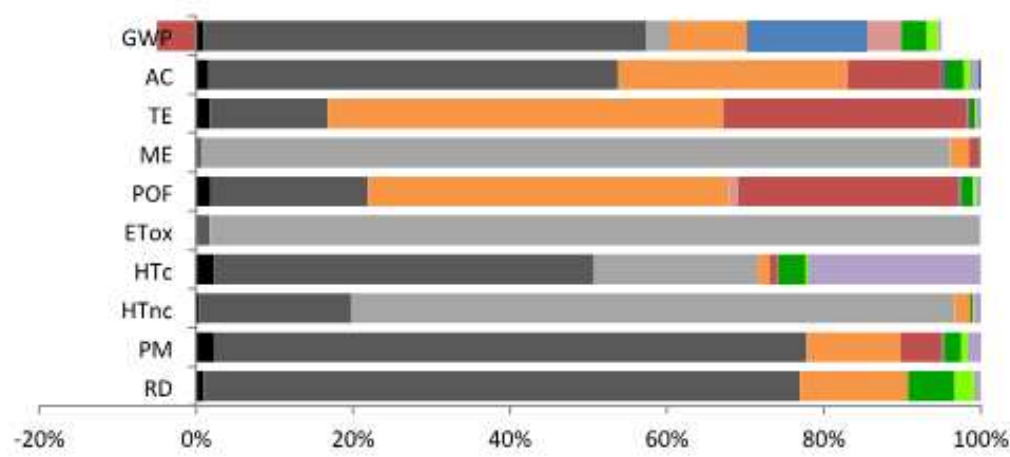

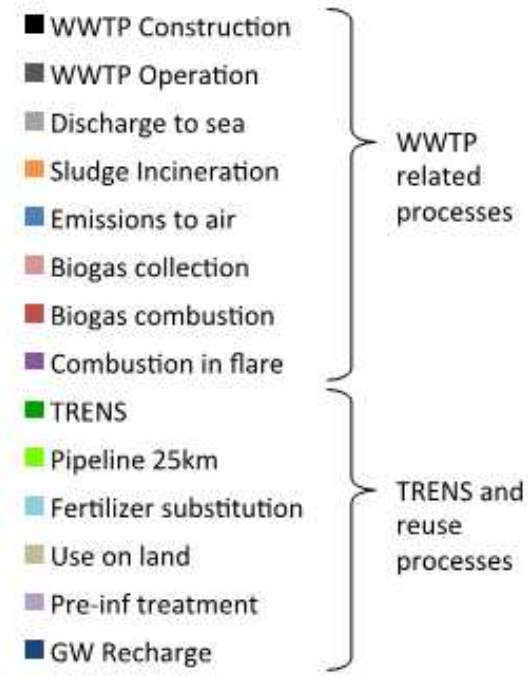

15 Figure 3: Percent contribution of individual processes each impact category for the three operating scenarios

16 (a) status quo, (b) fertigation, and (c) aquifer recharge. The life cycle phases of construction and operation are shown separately for the WWTP, but combined for other processes (e.g. TRENS, pipeline). Refer to Fig.

182 for abbreviations. 
Scenario B - difference from Scenario A

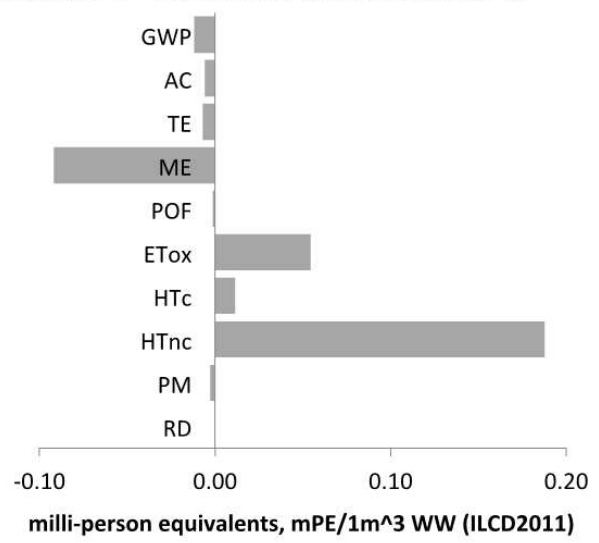

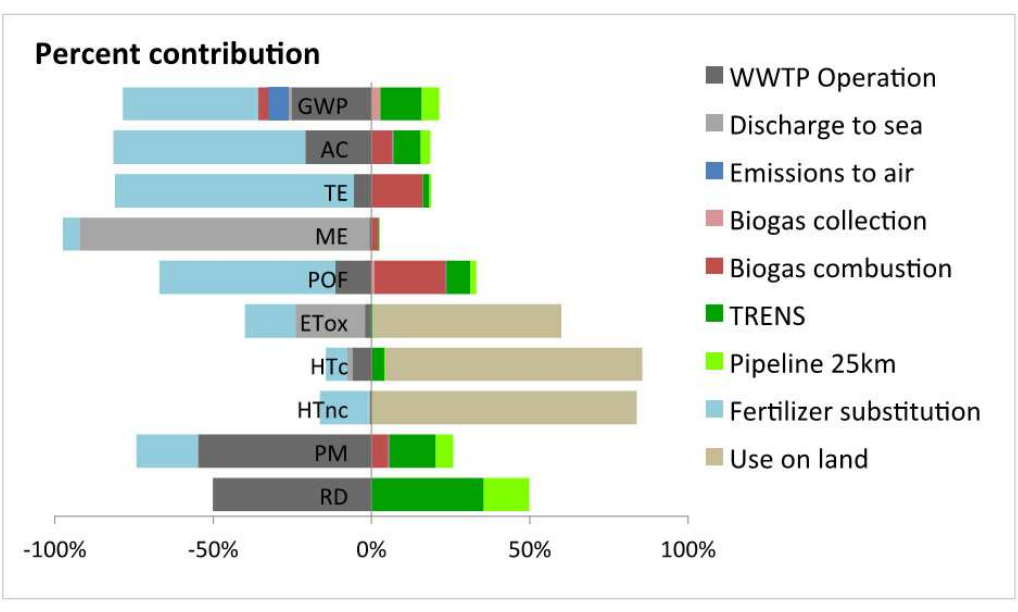

Figure 4: Environmental performance of fertigation with TRENS relative to baseline scenario (a) and the individual processes that contribute to the change (b). The left plot provides the magnitude of change, while

24 the right plot provides the reasons for that change. The percentage contribution plot is scaled such that the 25 sum of all processes is $100 \%$. Refer to Fig. 2 for abbreviations. 
Scenario C - difference from Scenario A

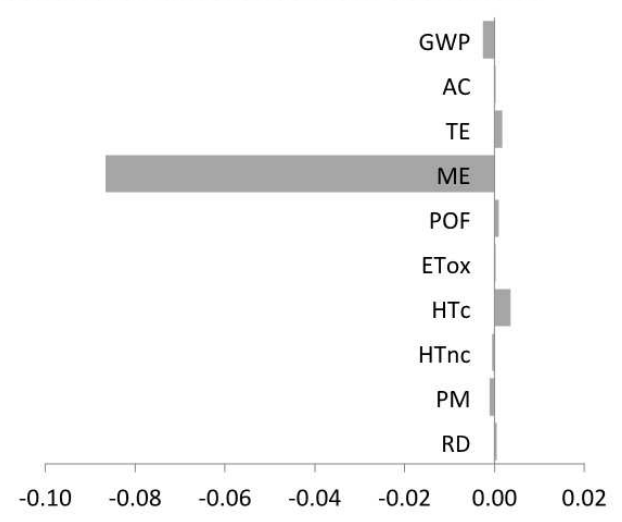

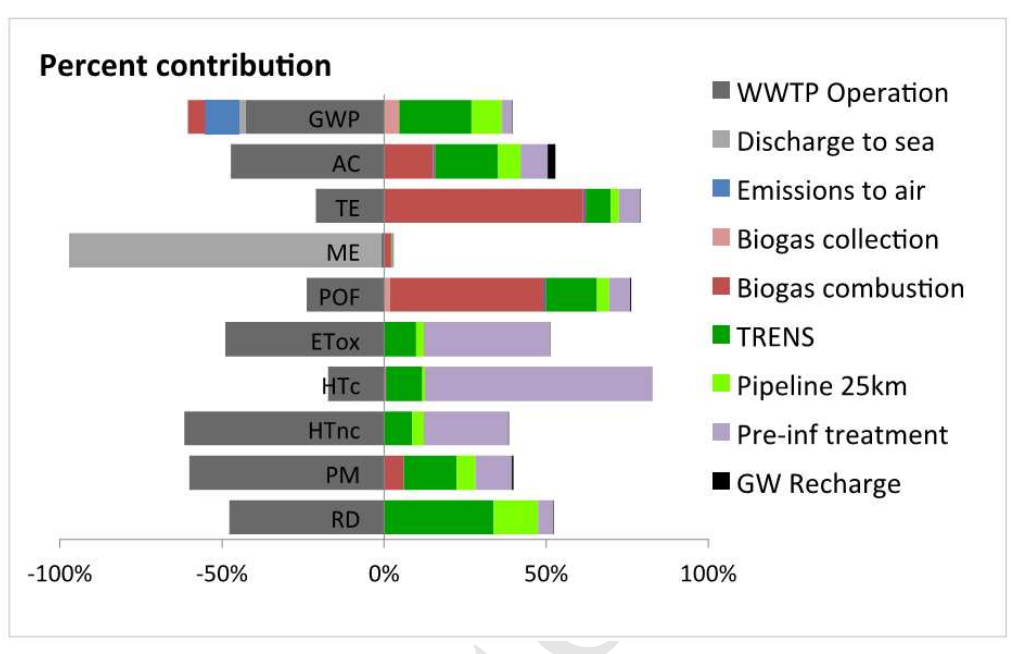

28 Figure 5: Environmental performance of aquifer recharge with TRENS relative to baseline scenario (a) and the individual processes that contribute to the change (b). Refer to Fig. 2 for abbreviations. 


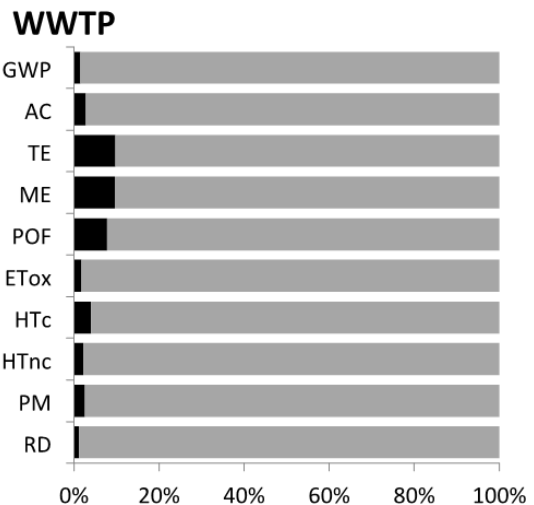

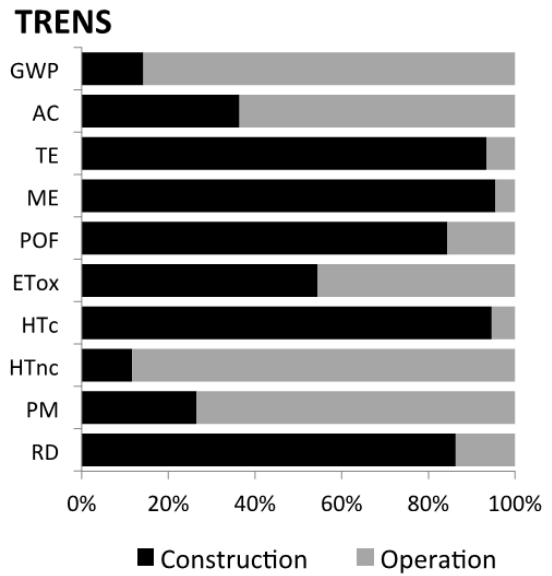

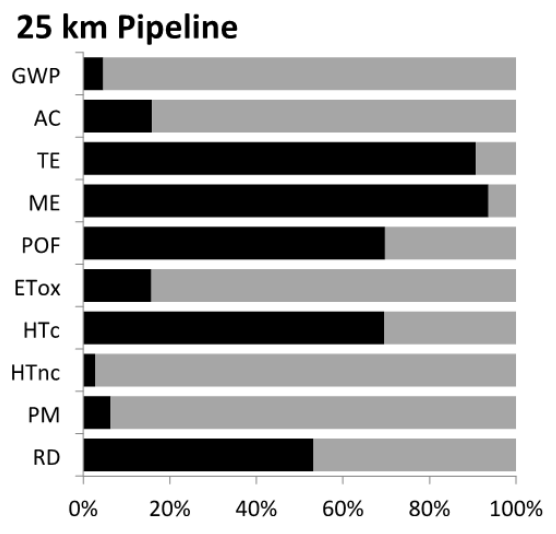

Figure 6: Relative contributions of construction and operation phase impacts in the B: fertigation scenario results for (a) the WWTP, (b) TRENS system and (c) pipeline. WWTP impacts are dominated by operation energy consumption, while TRENS and pipeline are more influenced by materials (plastics) used in the construction phase. Refer to Fig. 2 for abbreviations. 


\begin{tabular}{|c|c|c|c|c|c|c|c|c|c|c|c|}
\hline $\begin{array}{c}\text { Processes } \\
\text { exist in }\end{array}$ & Processes & GWP & $A C$ & $\mathrm{TE}$ & ME & POF & ETox & HTC & HTnc & PM & $\mathrm{RD}$ \\
\hline \multirow{8}{*}{$\begin{array}{l}\text { Scenarios } \\
A, B \text {, and C }\end{array}$} & \multirow{14}{*}{$\begin{array}{ll} & \text { WWTP construction } \\
\checkmark & \text { WWTP operation } \\
\checkmark & \text { Discharge to sea } \\
\checkmark & \text { Sludge incineration } \\
\checkmark & \text { Emissions to air } \\
\checkmark & \text { Biogas collection } \\
\checkmark & \text { Biogas combustion } \\
& \text { Combustion in flare } \\
\checkmark & \text { TRENS (EBP2R + PBR) } \\
& \text { Pipeline 25km } \\
\checkmark & \text { Fertilizer substitution } \\
\checkmark & \text { Use-on-land } \\
\checkmark & \text { Pre-inf treatment } \\
& \text { Groundwater recharge }\end{array}$} & & & & & & & & & & \\
\hline & & & & & & & & & & & \\
\hline & & & & & & & & & & & \\
\hline & & & & & & & & & & & \\
\hline & & & & & & & & & & & \\
\hline & & & & & & & & & & & \\
\hline & & & & & & & & & & & \\
\hline & & & & & & & & & & & \\
\hline$B$ and $C$ & & & & & & & & & & & \\
\hline & & & & & & & & & & & \\
\hline$R$ & & & & & & & & & & & \\
\hline & & & & & & & & & & & \\
\hline C & & & & & & & & & & & \\
\hline & & & & & & & & & & & \\
\hline
\end{tabular}

$40 \quad$ Figure 7: Contribution of processes to individual impact categories. Any process with a colouredblock 41 indicates it contributes $>5 \%$ to an impact category. 


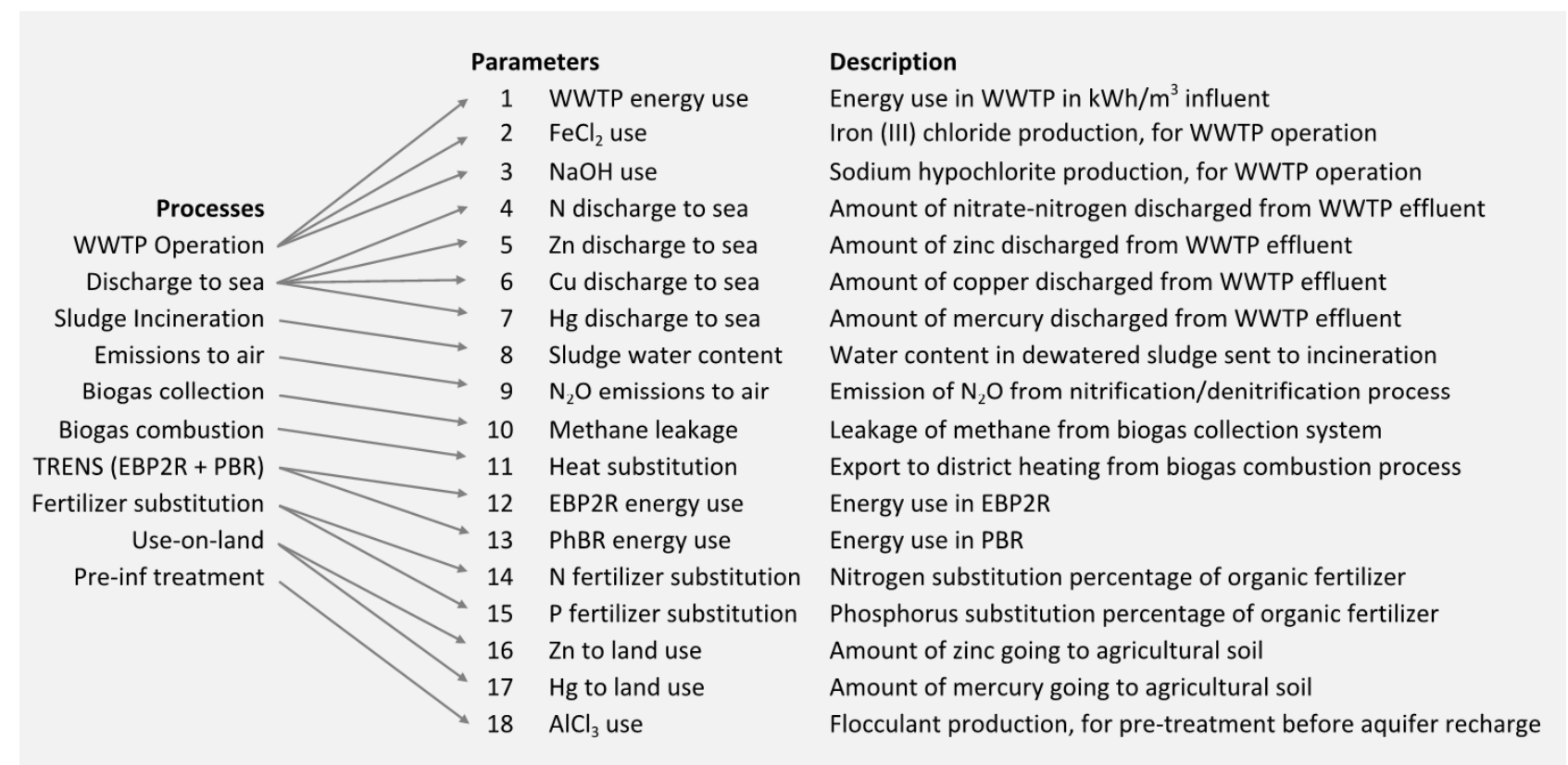

45 Figure 8: Key parameters identified from contribution analysis. 


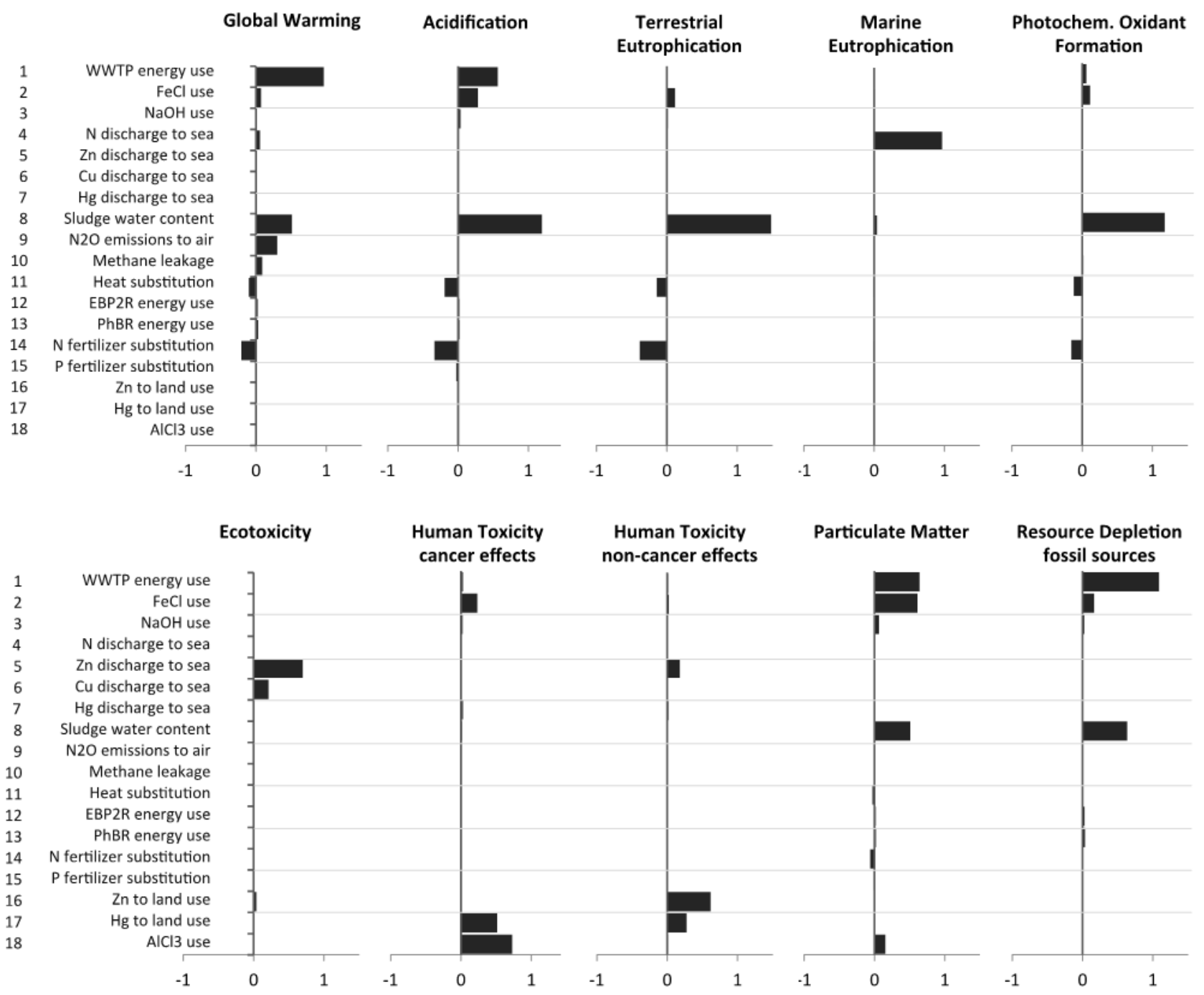

Figure 9: Sensitivity ratios showing the change in model output relative to change in parameter input. in parameter means decrease in model output). 
Highlights

- Development of wastewater biotechnology for resource recovery and reuse

- Recovery via low-SRT EBP2R combined with photobioreactor

- Water and nutrient reuse in irrigation-fertilisation combined with aquifer recharge

- Potential environmental impacts assessed using Life Cycle Assessment

- Key environmental risks linked to heavy metals co-recovered with nutrients 